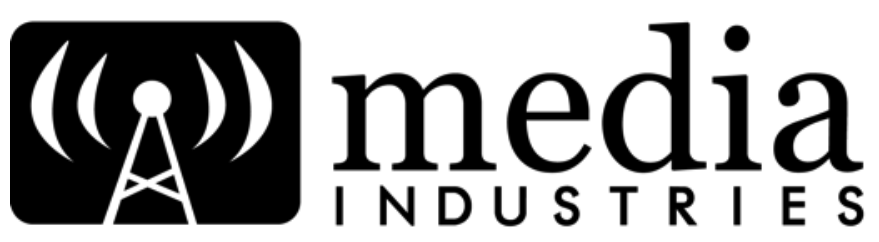

\title{
Hacking Radio History's Data: Station Call Signs, Digitized Magazines, and Scaled Entity Search
}

\author{
Kit Hughes, Eric Hoyt, Derek Long, Kevin Ponto, and Tony Tran ${ }^{1}$ \\ Miami Universitv and Universitv of Wisconsin-Madison \\ hughesk7 [AT] miamioh.edu
}

\begin{abstract}
:
This article uses scaled entity search (SES), a data mining technique and interpretive framework, to analyze radio stations' strategies of self-distinction and promotion within the broadcasting trade press. The authors model the technique by comparing the frequency of mentions of over two thousand call signs within the 1.5 million page digitized corpus of the Media History Digital Library. Using the ranked distribution of about two thousand results, the article compares the strategies of a top-trending station, WCCO Minneapolis, to those of stations at the twenty-fifth, fiftieth, and seventy-fifth percentile of results to achieve a bird's-eye view of station advertising practices across a much larger field of practice than is possible with traditional close reading. Although the prominence of often dramatic and eye-catching advertisements in journals such as Broadcasting and Sponsor suggest that station advertising was a widespread industrial practice, SES indicates that the practice was primarily taken up by only the largest stations, those with (local and national) network affiliation, and those represented by highly active station intermediaries.
\end{abstract}

Keywords: Radio, Broadcasting, Historiography, Big Data, Regionalism

The study and preservation of American radio is in the midst of a renaissance. The foundational works of American radio history explored the significance of key policies, ${ }^{2}$ the dominance of the national networks, ${ }^{3}$ the programs carried by those networks, ${ }^{4}$ and the influence of the medium on listeners and American culture. ${ }^{5}$ Recently, media historians have built upon this body of scholarship by complicating and expanding upon our understanding of radio as an industry and cultural form. Cynthia B. Meyers's A Word from Our Sponsor explores the pivotal role of advertising agencies in producing golden age American radio. ${ }^{6}$ In Points on the Dial: Golden Age Radio beyond the Networks, Alexander Russo "challenge[s] the image of radio during the network era as monolithic and static" and calls on scholars to pay more attention to the dynamic role of local stations within the industry. ${ }^{7} \mathrm{He}$ argues, "there is much more work that needs to be done to explain how local broadcasters operate as local entities, how their practices extend into the national and the global, and how they produce experiences that register as meaningful to listeners on multiple levels." 8 The Radio Preservation Task Force (RPTF), launched in 2014 by 
Christopher Sterling and Josh Shepperd, is an ambitious new initiative making progress toward this end. By facilitating collaborations between archivists and scholars, the RPTF is at the forefront of preserving, documenting, and studying local radio programming. ${ }^{9}$

We seek to contribute to this recent turn in radio historiography by modeling how data mining techniques can be used to create a broad comparative infrastructure for better understanding the heterogeneity of local broadcast station practices. As a test case, we employ digital tools to analyze stations' construction and promotion of their markets via trade journal advertising. To appreciate why a station would advertise or seek publicity in a national trade paper, one needs to understand the basic business model of commercial broadcasting in the 1930s, '40s, and '50s. Stations sold airtime to sponsors, and, in some cases, they were local sponsors (the Cook Paint and Varnish Company owned and operated a Kansas City radio station, WHB, for seventeen years). ${ }^{10}$ However, stations were also keen to secure the business of national sponsors, which generally either bought time on the networks (which allowed for the reaching of most or all affiliate stations at once) or purchased spot advertising (which enabled reaching audiences on a selective basis by market). The spot advertising marketplace offered a profit center for local stations, which retained a larger percentage of revenue from spot sales than the network advertisements they aired, and supported a coterie of intermediaries called station representatives, who acted as middlemen in the transactions between local stations and national advertisers. ${ }^{11}$ Within this industry environment, stations were incentivized to distinguish themselves from their competitors and increase their sales of spot advertising. Trade papers, read by industry insiders, offered one method for stations to achieve this distinction. But what types of stations were most likely to pursue this method? And what strategies did they employ within the trade press to make markets meaningful to advertisers, station representatives, and other industry figures? To pursue these questions, we turned to data mining.

Utilizing the Arclight software application and a process called scaled entity search (SES), we queried 2,002 station call signs within the 1.5 million-page corpus of the Media History Digital Library (MHDL), which includes lengthy runs of several broadcasting journals, including Radio Digest, Radio Mirror, Broadcasting, and Sponsor. Much like Twitter analytics, Arclight and SES can help scholars identify "trending" people, companies, and content in media industries publications and discourse. A public version of the Arclight software will soon be available, allowing users to run scaled entity searches to generate data and visualizations. ${ }^{12}$

SES combines two facets: a technical procedure for generating results, and an interpretive framework for analyzing those results. The interpretive framework stresses three elements of the search process - the entities, the corpus, and the digital - as well as the relationships among them. This framework structures the first half of this article, which discusses call letters as search entities, the MHDL as corpus, and SES as a process of critical digitization. The second half of this article discusses our case study and results. One of the chief benefits of Arclight and SES is the comparative perspective they offer by virtue of scale. Although media history scholarship is dominated by the case study, these studies' generalizability is not always acknowledged. SES offers a partial corrective to this problem by offering a mechanism for contextualizing case studies within the broader film and broadcasting publishing landscape. Using data mining techniques, we chose a prominent, outlying station as our case studyWCCO Minneapolis, a midsize market station that received industry attention quantitatively comparable to a New York or Chicago station-and used the SES method to develop a comparative framework that allowed us to check that station's coverage against that of stations across the entire spectrum of North American broadcasting outfits. While tracing WCCO through 
the MHDL enabled us to develop a sense of how local broadcasters used the industry press to position themselves favorably to advertisers and other participants within the industry, using SES to compare WCCO to other key stations suggests that such direct engagement with the trade press was not a majority practice, with certain kinds of stations far more likely to participate than others.

This ability to provide a framework for comparison nearing grand-and, potentially, comprehensive-scale, enables what we might call "computationally contextualized" case studies. To determine the representativeness or singularity of our case, we can employ comparative analysis made possible by simultaneously situating our case against thousands of others (in our example, other stations) - an undertaking nearly unthinkable without the aid of digital tools. Furthermore, by seeking remarkable historical players and patterns from a quantitative standpoint, rather than allowing preexisting canons and narratives to obscure the unexpected, we can explore broader patterns that previous scholarship has left underexamined. This comparative approach - which both reveals unexpected new avenues of research and allows for comprehensive comparison to deepen the quality and scope of our claims - requires a keen understanding of the entities being compared at the beginning of the SES process.

\section{The Entities: Station Identification}

Prior to 1912, wireless operators' use of call letters to identify the destination and origination of messages was haphazard and idiosyncratic. Call signs ranged from one to three letters and often lacked any semantic or systematic meaning. ${ }^{13}$ An International Radiotelegraphic Convention was held in 1912 as part of a series of measures to facilitate open communication between station operators. Convention delegates scrapped existing call signs to create a new three-letter system that carved up the alphabet into sets of consecutive combinations and assigned them to different countries based on their perceived need. ${ }^{14}$ The United States was allotted signs beginning with $\mathrm{N}$ and $\mathrm{W}$, as well as stations from KDA to KZZ (inclusive). ${ }^{15}$ With a few exceptions, early US policy reserved N-- call signs for the Navy, W-- call signs for commercial stations on the Atlantic coast and Gulf of Mexico, and K-- call signs for commercial stations on the Pacific coast and Great Lakes. ${ }^{16}$

With these arrangements in place, station call letters quickly became "big data." Though only five licensed AM stations were in operation at the start of 1921, this number grew to over 500 stations by 1923. The same figure rose to almost 700 in the ensuing decade, before falling by roughly 15 percent during the Great Depression and rebounding once again to about 830 stations by 1940 . Ten years later, the broadcasting landscape included over 2,000 AM stations, more than 700 FM stations, and almost 100 TV stations - each of which had a unique term of identification that made it highly searchable across any heterogeneous corpus. ${ }^{17}$

While regulations charged radio inspectors to "use their discretion in the award of calls, avoiding, of course, duplications," it is unclear whether early licensees had any input regarding specific combinations to correspond with their location, frequency, or name. Station lists indicate little perceptible correspondence between call letters and station identity, suggesting that even if allowed (unlikely), "vanity" call letters were uncommon. Furthermore, when increased demand resulted in the expansion of call signs to four letters, broadcast license reports indicate that the FCC distributed calls through an orderly, alphabetical system. ${ }^{18}$ This policy appears to have shifted sometime in the 1920s, when stations were permitted to request available call letters to suit their marketing interests. Custom call signs became common, and might refer to a station's location (WACO), owner (Omaha World-Herald's KOWH), frequency 
(KLVI, a Beaumont, TX, station broadcasting at $56 \mathrm{kHz}$ ), or slogan (KPIG at "107 Oink 5"). ${ }^{19}$ While these call signs helped stations insert their brand into their mandated on-air station identifications, others chose calls that would simply be easy to remember (WHEN and WAGE were both tied to the same Syracuse station). As addressed below, this interest in vanity calls impacts our ability to undertake computerized analysis.

The systematic assignment of call letters to local stations was a crucial factor in our decision to apply SES to broadcasting history. Frequently, data mining projects must engage in complex and imperfect disambiguation processes to sort data associated with identical terms, but different referents (e.g., Broadcasting the publication and "broadcasting" the practice). ${ }^{20}$ Because station call letters are largely - though, as noted, not completely - unambiguous, they indicate their referent stations relatively reliably in a sea of data as large as the corpus of the MHDL. Using The 1948 Radio Annual, Kit Hughes generated a list of 2,002 unique station IDs along with associated metadata about each station, such as its city, wattage, frequency, network affiliation, and owner. This resulted in a list of unique named entities - each of which could be queried in the MHDL corpus.

\section{The Corpus: Radio Periodicals and the Media History Digital Library}

The Radio Annual, which we used to develop our list of 2,002 station IDs, was a product of the robust publishing business that grew alongside the American broadcasting industry. ${ }^{21}$ The $N$. W. Ayer $\mathcal{E}$ Son's Newspaper Annual Directories contain entries for 241 periodicals related to "radio" or "wireless" that emerged between 1920 and 1950 (likely a low figure).22 In the MHDL, station call letters appear most frequently in general-readership magazines-where they occurred primarily in the context of program listings - and industry trade papers. While both of these genres underwent significant changes between the early 1920s and the early 1930s, our present research questions focus on the industry trades. Understanding these periodicals, and how they changed over time, provides crucial context for interpreting search results.

The first radio trade papers were heavily focused around merchandising, with titles such as The Radio Dealer (established 1922), Radio Retailer and Jobber (established 1922), and the Western Radio and Refrigeration Journal.23 These retail-oriented trade papers were joined by a new breed of radio publication in the 1930s and 1940s - for example, Broadcasting (established 1931), Radio Daily (established 1937), and Sponsor (established 1946)-that cared more about selling advertising and programming than they did about radios and refrigerators. From their point of view, the key marketplace transactions occurred between advertisers and stations-often through intermediary station representatives. Whereas The Radio Dealer was quick to object to sales methods that bypassed the retailer, the new trade papers condemned any developments that threatened the rapidly growing businesses of advertising sales and program production. ${ }^{24}$ Broadcasting, based in Washington, DC, was especially critical of government regulation of the radio industry. ${ }^{25}$ Its strong credibility and large readership among advertisers made it an ideal site for self-promoting stations looking to find more sponsors.

Other key genres of radio magazines included technical journals (e.g., Radio Engineering and Radio Manufacturer), radio hobbyist magazines (e.g., CQ and QST), and magazines published by individual stations (e.g., the Kansas City-based station WHB's magazine, Swing). More scholarship can and should trace the history and influence of these and other magazines. However, for the purposes of our analysis, our focus remains on trade journals. We also acknowledge that the MHDL's collection is much stronger in some areas than others, and that digital availability has influenced our decisions about which types of journals to concentrate on. 
As of 2015, the MHDL is fairly robust in its holdings of broadcasting yearbooks (The Radio Annual, 1938-1964), trade papers (Broadcasting, 1931-1945, 1949-1963 and Sponsor, 1946-1963), and general interest magazines (Radio Digest, 1923-1933, Radio Stars, 1933-1938, and Radio Mirror, 1933-1963). 26

The MHDL is more limited, however, with regard to radio technical journals and hobbyist magazines. Although the MHDL's runs of Radio Age (1922-1927) and Radio Broadcasting (19221930) contain material related to hobbyists and the medium's technological development, the MHDL and its partners have not yet digitized the most significant radio-hobbyist and technical publications from the 1930s-1950s. Fortunately, many of these journals have been scanned by David Gleason for his remarkable digital library, AmericanRadioHistory.com. However, we were unable to include AmericanRadioHistory.com's scanned magazines in our analysis because Arclight's workflow depends on files being stored on the Internet Archive (used by the MHDL, Library of Congress Packard Campus, and Library of American Broadcasting for data hosting and preservation). The significance of these data storage decisions becomes clearer in the next section, which offers a more detailed explanation of scaled entity search and the Arclight app.

\section{The Digital: Scaled Entity Search}

Scaled entity search enables "distant reading" of a corpus (in our case, the MHDL) through the lens of chosen data points (the station calls). SES can search thousands of entities at once, maintaining the benefits of search-precision data mining informed by domain expertisewhile muting some of search's most pressing failings - confirmation bias, destruction of context, and filtering of contrary evidence. In addition to comparing individual stations as they trend through time and across sources, SES allows us to learn more about the corpus itself and the perspective and scope of individual magazines.

Our design of SES is informed by a desire to increase nonexpert access to digital tools. We understand access in terms of transparency and adaptability to humanities concerns as well as tools' distribution and interface usability. To engage concerns over digital methods' "black boxes," we pursued a technical method based on counting rather than the increasingly sophisticated algorithms that have gained favor in topic modeling and other data mining practices. Using a more basic technical system introduces different problems, such as the increased need to preprocess data (which we address below). Because of the transparent and self-reflexive nature of SES, however, we believe it is a good introduction to the promise and pitfalls of digital analysis for those unfamiliar with humanities computing. Our particular experiences in the development and use of SES support the notion that struggling with the structural limitations of research is not reserved for "analog humanities" but is a constitutive element of digital work.

As a process, SES works in multiple stages. First, users compose an entity list of the terms they wish to search for-in our case, the call letters of 2,002 stations. Users input this list into the Arclight software app. The software then queries each individual entity through the MHDL search index, Lantern, just as if a user had entered a keyword in a search box. For each entity entered, the app returns crucial metadata relating to each term (the number of page hits per year and those same page hits expressed as a percentage of the total digitized pages from a given year). Arclight provides this information to the user in a Comma Separated Value (CSV) file that can be graphed and visualized in standard spreadsheet software. Arclight also visualizes the data as an interactive line graph (complete with links to the original hits). ${ }^{27}$ 
This technical process is only the first half of SES. The second process utilizes an interpretive framework designed to help scholars remain critical about their results. Even a bird's-eye view of the entities and journals can be quite overwhelming, given the potential scale of SES queries; the interpretive framework assists scholars in managing this scale and qualifying their claims. Developed as a series of questions focused on the three major elements of the SES process (the entities, the corpus, and the digital-here, the station calls, broadcast trade journals, and Arclight), the framework ideally progresses from each of these process points to the next, reflecting on how different factors (e.g., choices made when constructing entity lists, fallibility of optical character recognition, copyright) shape the questions we can ask and how we might interpret our results. It is also crucial to attend to the relationships between these fields, such as the disambiguation of the entity list required by digital analytics. ${ }^{28}$ Ultimately, the interpretive framework seeks to reinforce the accessibility of SES to researchers concerned with managing uncertainty and qualifying claims by making the limitations of the technical method as transparent as possible.

While this interpretive method points to new questions we must consider when undertaking digital analytical research, it also invokes problems embedded in "analog" forms of research, such as managing a fluctuating corpus. Furthermore, it pushes users to consider the extent to which our work is already constituted by digital technologies and the ways in which the tools we currently use, such as search algorithms and article databases like ISTOR, shape our research. Indeed, much of the above discussion of call signs was shaped by the public availability of digital resources, from amateur historians using the web to coordinate research efforts on a complex and geographically distributed problem, to the digitization efforts of various government and educational institutions such as the FCC and HathiTrust. While these sources may make research easier, faster, and more accessible to a wider group of users, we must be careful not to let digital accessibility overshadow information contained within more difficult-to-access sources. By constantly examining the role of digital technologies in the research we undertake and distribute, we can better account for the forces that weigh on our arguments - no matter the technological form of our data.

\section{Computational Context for WCCO: Broadcasting History's “Top-Trending" Stations}

We now turn to the results of our scaled entity searches, focusing our attention on the top 100 most-discussed stations (see appendix 1). We hoped to use our SES results to identify predicted patterns (to test the relative accuracy of the method) as well as locate any outliers that might point to potentially interesting case studies. Our list of the top 100 stations required a certain amount of processing to discount false positives (i.e., hits prior to stations' founding) and unacceptably ambiguous results. These included around fifty "vanity" call letters and common English words or names (WITH returned nearly a million hits, while the unambiguous KDKA returned only 8,386). We had no choice to but to discard these stations. SES is not equipped to handle potentially important but ambiguous entities (WITH, for example, self-advertised heavily in both Broadcasting and Sponsor). However, for the purposes of our analysis - for which we were interested in developing a broad sketch of how stations' strategies of self-distinction appeared across the wider local radio landscape (rather than, for example, identifying every major self-promoting station) - the loss of roughly 2.5 percent of our entities should not unduly interfere with our results. ${ }^{29}$

As expected, many stations topping the list served major mid-twentieth-century markets (Chicago, Philadelphia, New York): 


\begin{tabular}{|c|c|c|c|}
\hline Station & Market & $\begin{array}{l}\text { Significant Network } \\
\text { Affiliation(s), 1926-1963 }\end{array}$ & $\begin{array}{l}\text { Page } \\
\text { Hits }\end{array}$ \\
\hline KDKA & Pittsburgh & NBC & 8,386 \\
\hline KYW & Philadelphia & NBC & 7,989 \\
\hline WBBM & Chicago & CBS & 7,752 \\
\hline WBZ-WBZA & Boston & NBC-N.E. Regional & 7,644 \\
\hline WLS & Chicago & $N B C, A B C$ & 7,339 \\
\hline $\mathrm{KHJ}$ & LA & CBS, Mutual-Don Lee & 6,787 \\
\hline WGN & Chicago & Mutual, NBC, CBS & 6,479 \\
\hline WSB & Atlanta & NBC & 6,393 \\
\hline WGY & Schenectady & NBC & 6,317 \\
\hline WCCO & Minneapolis & CBS & 6,307 \\
\hline $\mathrm{KFI}$ & LA & NBC & 6,302 \\
\hline KGO & San Francisco & $N B C, A B C$ & 6,253 \\
\hline WFAA & Dallas & NBC, ABC, Texas Quality & 6,177 \\
\hline WMAQ & Chicago & NBC, CBS & 5,903 \\
\hline WNEW & New York & - & 5,863 \\
\hline WHAS & Louisville & NBC, CBS & 5,614 \\
\hline WJR & Detroit & NBC, CBS & 5,549 \\
\hline WRC & $D C$ & NBC & 5,441 \\
\hline WSM & Nashville & NBC & 5,280 \\
\hline WGR & Buffalo & CBS, NBC & 5,154 \\
\hline
\end{tabular}

Not only were almost all top-ranked stations each affiliated with a major network during a significant portion of the study's timeframe, many in the top twenty were owned and operated by one of the networks (e.g., KYW, WMAQ, WBZ). Furthermore, many of these stations reached early clear-channel status - protection from nearby interference and permission to broadcast at high power, generally fifty thousand watts, to reach a more geographically dispersed audience.

Other shared characteristics complicate our ability to analyze differences across all of the stations' results. The first of these is age. Older stations, because they appear in more volumes and annual reports, tend to cluster at the top of rankings. The second is stations' extension of their radio call signs to their television operations: WLS-TV, for instance. Arclight returns both WLS and WLS-TV for the "WLS" entity, artificially increasing the number of hits for radio stations that lent their calls to television stations. Visualizations - such as a line graph charting each station over time-could help identify stations affected by this problem, since calls used 
for both radio and television would likely exhibit a bump or sustained rise in the 1940s and 1950s as license holders diversified their broadcast operations.

The overall instability of station IDs presents additional problems when attempting to isolate instances of a unique entity. While some stations, such as KDKA or WSB, might retain their call letters due to their prestige and marketing value, others might likewise change their IDs to reflect shifts in ownership or new branding efforts. The AM station known today as WCBS began broadcasting in 1924 in New York City as WAHG. Shortly after its inception, owner Alfred H. Grebe petitioned the FCC to change the call sign to WABC (letters which up to that time described a station in Anderson, Indiana, owned by the Fulwider-Grimes Battery Company) to reflect the name of his company, the Atlantic Broadcasting Company. Although CBS purchased the station in 1929, it was not until 1946 that WABC switched its call letters once again, this time to indicate its alignment with the network and distinguish itself from its newest chain competitor, ABC, founded in 1943 (the Springfield, Illinois, station to that point known as WCBS changed its call sign to WCVS). As this example indicates, it was not uncommon for a station to change its call, often leading to changes in station IDs across the dial. As a result, even when we can pinpoint hundreds of call letters that have no relation to existing English words or sibling television stations, we must still confront issues of disambiguation. These are the very types of limitations that SES's interpretive focus on "entities" highlights. Because disambiguation of this kind would be incredibly difficult to achieve through any sort of automated process, this becomes a site of vital human intervention.

After exploring the rough contours of our SES metadata, we turned to a more human scale of analysis: the case study. We hoped to compare the bird's-eye view of SES calculations with onthe-ground analyses of the original materials. WCCO Minneapolis possesses many of the characteristics shared by the top-ranked stations listed above. Founded as WLAG in 1922, the station adopted its current call sign, WCCO-standing for Washburn-Crosby Company -in 1924, placing it among the earlier stations on our list. ${ }^{30}$ Although WCCO affiliated with the NBC Red network in 1928, it shifted allegiances only four years later, when it was purchased by CBS. WCCO bore the mantle of owned-and-operated ("O\&O") status until 1954, when CBS relinquished control to comply with ownership regulations (WCCO remains a CBS affiliate). In addition to serving as an O\&O for over two decades, WCCO has been a clear-channel station operating at fifty thousand watts - since at least 1932. ${ }^{31}$ Despite these shared similarities, WCCO stands apart from many of the other stations at the top of the list given its location in a relatively smaller Midwest market. Using WCCO as our case study, we hoped to balance our interests in what pushes a station to prominence - the factors that contribute to "trending" - with what might distinguish WCCO as different.

Even when narrowing our focus to one station, the scale of our data continued to pose difficulties. Over six thousand pages across the MHDL mention WCCO. Following Lev Manovich and his colleagues at the Software Studies Initiative, we asked how we might-with more modest ambition-compare these several thousand images. ${ }^{32}$ Although Manovich combines automated analysis of image characteristics like shading and detail with visualizations that depict the entire dataset-in his example, over one million pages - we found that Lantern's search feature, which provides a thumbnail preview of up to one hundred pages simultaneously, gave us enough "distance" to identify patterns and distinguish station advertisements from the rest of the data.

We developed a series of research questions that required a return to the text with traditional 
close reading: (1) What "strategies of distinction" did WCCO use to position itself and its market within the trade press? (2) In which publications did such advertisements most frequently appear? (3) Did strategies shift depending on the journal-and consequently the audiences that advertisements hoped to reach? And finally, but most significantly in terms of the potential contribution of digital methods like SES, (4) how did WCCO's practices compare to the rest of the local station landscape?33 In other words, were station advertisements - one of the primary ways stations could directly increase their standing in our SES results-an important factor in station trending rates?

\section{WCCO, "The Paul Bunyan Buy!"}

Trade advertisements account for 455 of the 6,225 page mentions of WCCO across the MHDL corpus. In Broadcasting and Sponsor - the two journals most frequently featuring such ads - they amount to roughly 14 percent of WCCO mentions. Both before and after WCCO affiliated (and, later, became an $\mathrm{O} \& \mathrm{O}$ ), most of the advertisements featured the station itself, promoting its geographical reach, talent, and popularity with local audiences. Often, the same campaigns were split across Sponsor and Broadcasting, with ads in annuals and Variety conforming more to each journal's house style.

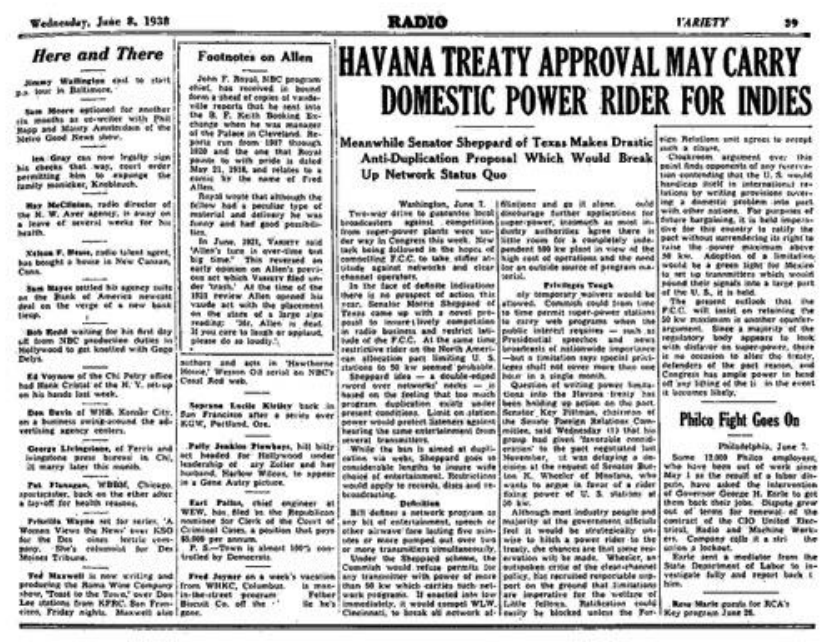

48,600 MINNEAPOLIS-ST. PAUL RAdIO HOMES

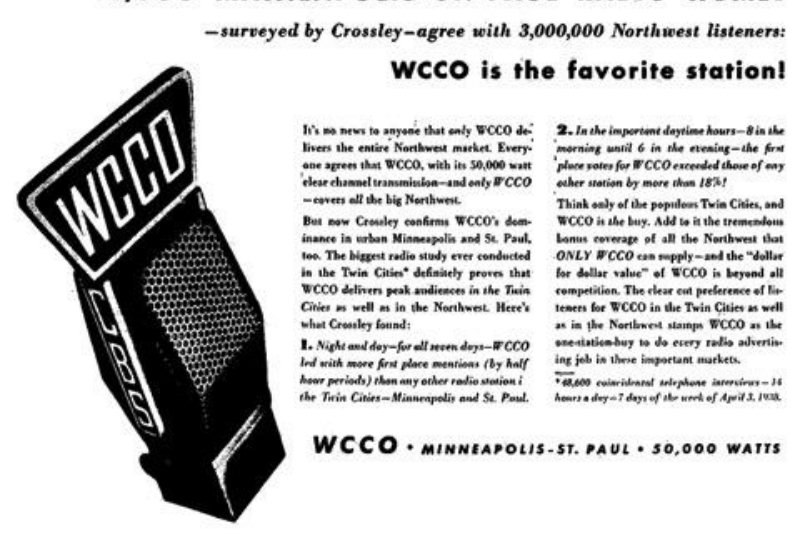

Figure 1. Variety, June 2, 1938: 39. 
Following WCCO's partnership with CBS, the station became incorporated in many advertisements for CBS Radio Sales (later CBS Spot Sales), the network's advertising service that allowed sponsors to precisely place ads in local markets, choosing the time of day and the program during which their ad would appear. ${ }^{34}$ This corresponds to how WCCO-TV appeared across the MHDL, both in single-station ads and in advertisements for Free \& Peters (later Peters, Griffin, Woodward, Inc.)-their station representatives, the intermediaries who developed local markets and worked with advertisers and sponsors to place their ads. ${ }^{35}$ WCCO also appeared in advertisements for technical equipment and syndicated programming as a sort of testimonial to the product's success, albeit rarely. The utility of WCCO's call letters to these diverse users and institutions contributed to its proliferation in the corpus, representing about 20 percent of their advertising hits.

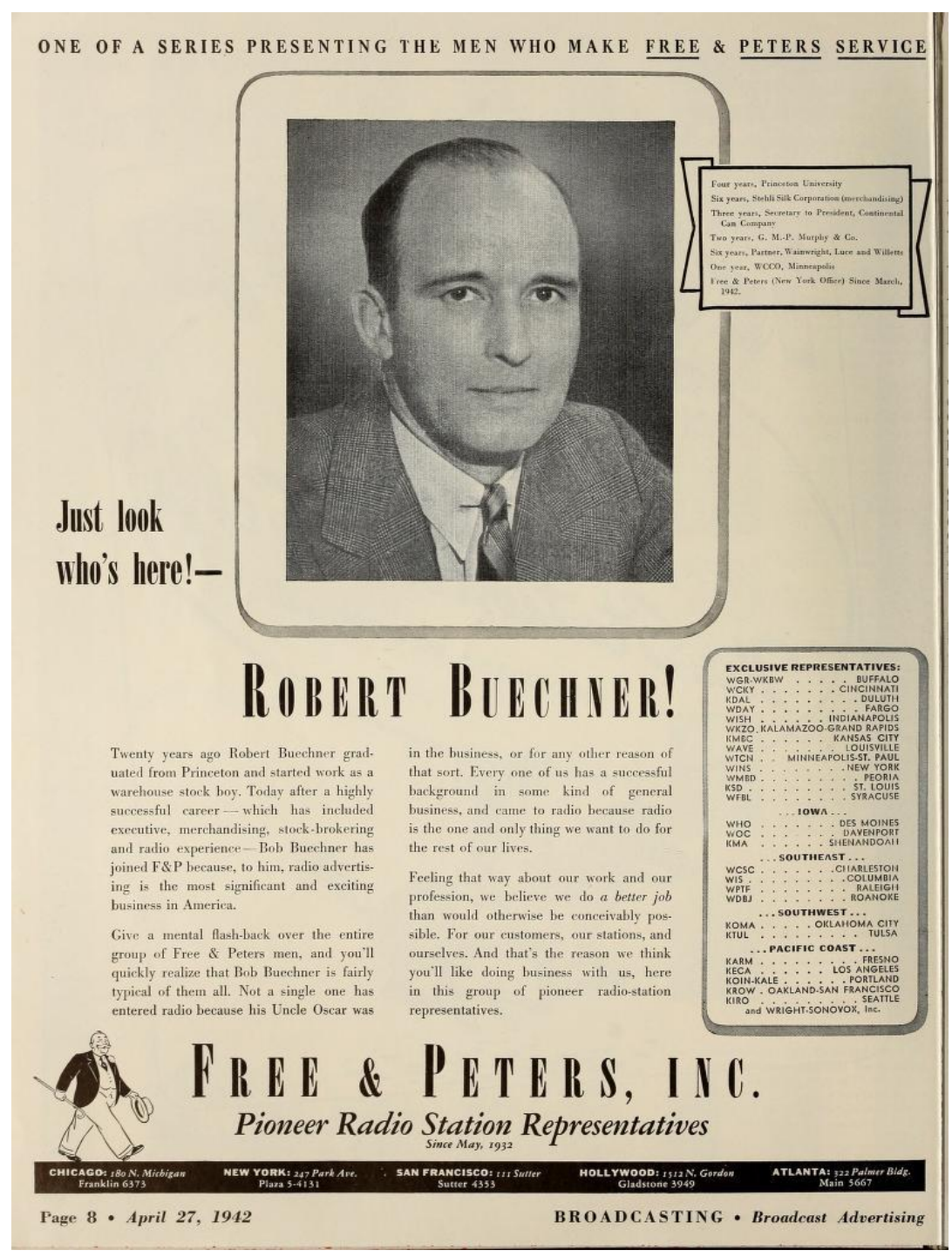

Figure 2. Broadcasting, April 27, 1942: 8.

By looking at the journals in which these ads tend to appear, we can develop a better sense of how WCCO and its representatives thought of its other audience-not the listeners at home, but the advertisers, sponsors, and other business leaders interested more in the station's performance than its programming. Although Broadcasting returned almost 400 percent more 
total hits for WCCO than Sponsor (2520 vs. 551), advertisements were split comparatively evenly between Sponsor (168) and Broadcasting (255), with a handful appearing across Variety (16), U.S. Radio (10), and The Radio Annual (6). ${ }^{36}$ What strategies did WCCO and its representatives use to appeal to industry professionals? How did they distinguish WCCO and its market amid the increasing national scale of broadcast operations? Below, we discuss three major strategies of self-promotion - facts and figures, local identity, and local relationships - used by stations and their representatives to gain distinction amid an increasingly crowded media landscape.

The most prevalent strategy spanning the three decades of WCCO advertisements under analysis is an emphasis on facts and figures. This includes ratings, receiving sets, population, spot rates, retail market and summer spending dollars, and market share. Drawing on their own accounting (e.g., letters received) as well as ratings and diary reports from ratings companies such as Hooper, Nielsen, and Benson and Benson Inc., WCCO centered campaigns around the popularity of their programs and the large size and economic power of their audiences. ${ }^{37}$ This emphasis on quantifying audiences coincided with broadcasters' persistent push, beginning in the 1930s, to develop accurate accounting systems for their audiences that could rival magazine circulation numbers. ${ }^{38}$ We might also consider this approach in relation to "hard sell" advertising strategies, which assumed the rational decision making of audiences and thus sought to provide straightforward (in this instance, quantifiable) "reason-why" copy that emphasized how the product in question suited audiences' needs. ${ }^{39}$

Often, these advertisements tuck figures into an umbrella campaign, such as WCCO's "Good Neighbor to the Northwest" series, which featured whimsical graphics alongside short stories describing the appeal of WCCO programs (sports, school closing information, news, farm entertainment) to their audience. In the 1943 "Most-Crowded Newsroom in the Northwest," for example, a description of the history of news programming on WCCO was also sure to mention the almost four million "Northwest folks" who had depended on WCCO for the previous nineteen years. ${ }^{40}$ Other campaigns focused almost entirely on the figures themselves. ${ }^{41}$ One long-running early 1960s campaign forgoes any sort of narrative appeal to emphasize WCCO's high market share. In these ads, it is not unusual for numbers to become the primary graphic interest, suggesting to the reader that the "facts" speak for themselves. ${ }^{42}$ In addition to audience-focused facts and figures, one other number routinely appears in WCCO ads: fifty thousand - the maximum wattage (power) of a clear-channel station. The repetition of "50,000" in station advertisements and CBS network advertisements emphasizing their stable of fullpower stations situated WCCO as a powerful and prestigious behemoth that could reach massive audiences (and "where it counts most," i.e., in the most lucrative markets). ${ }^{43}$ The incredible reach of those fifty thousand watts is reinforced in many ads through maps that depict radio signals spanning state lines and dispersed localities, visibly building and binding a market otherwise conjured primarily through numbers. ${ }^{44}$

As the example of this map suggests, although sponsors investing in spot buying were interested in the size of a station's potential audience, they were also concerned with the specific attributes of a given market. Early ratings systems like Hooper's brief telephone surveys and Nielsen's Audimeter were unsuited to providing qualitative data about audience demographics; establishing markets' qualitative value became the work of station representatives. As Alexander Russo details, these workers - tasked with marketing stations, audiences, and markets to potential sponsors through projects like these advertisements - were responsible for drawing the boundaries of local markets and making them meaningful within the broadcasting industry. ${ }^{45}$ 


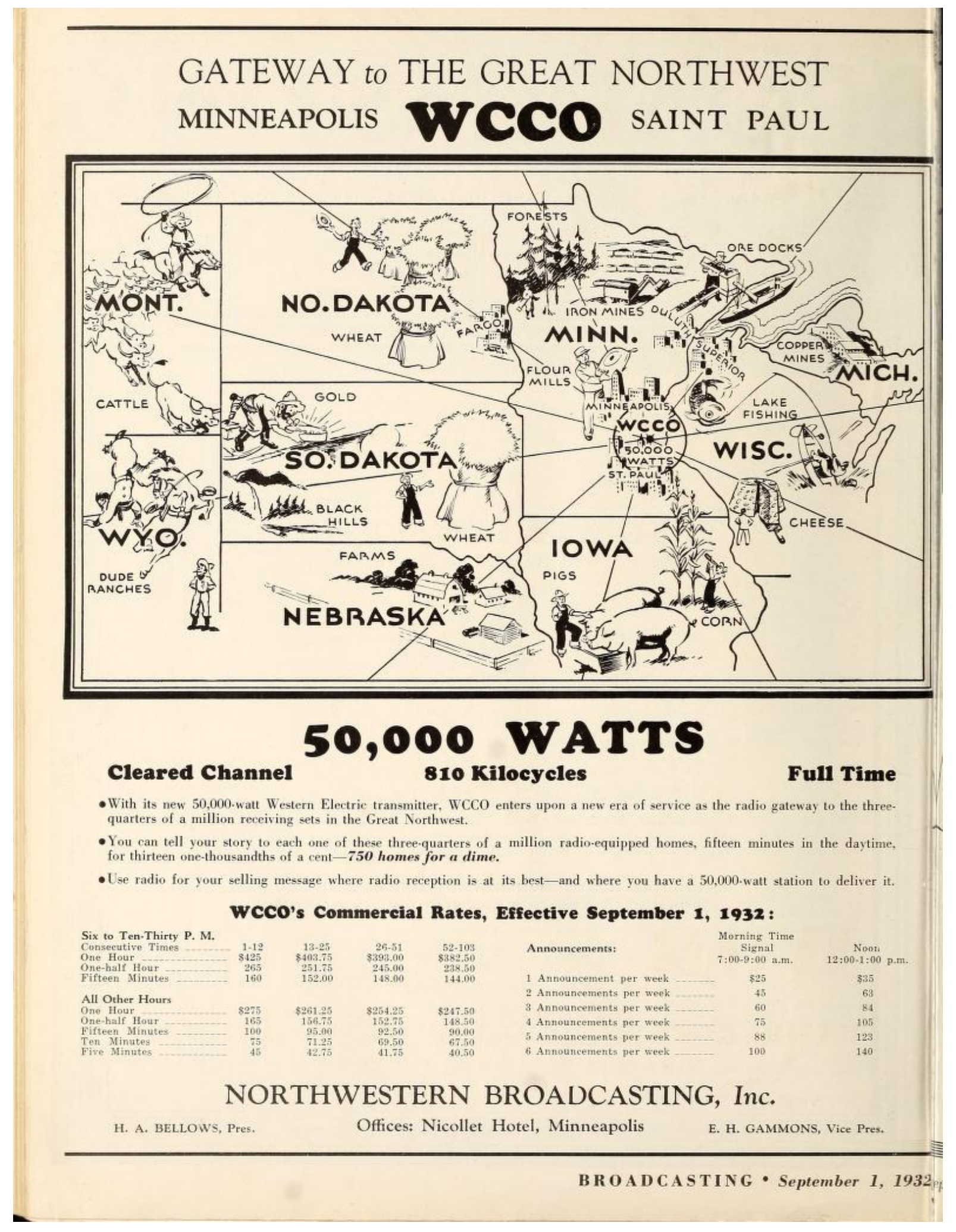

Figure 3. Broadcasting, September 1, 1932: 2. 
While the "facts and figures" noted above represented one avenue by which representatives might use certain knowledge forms to establish and classify stations' markets, another prevalent strategy for WCCO was drawing on preestablished local culture and identity. One of the station's major campaigns built on the myth of Paul Bunyan, aligning WCCO's accomplishments with tales of the giant's astounding feats to establish the station's size and power while at the same time alluding to the "folksy" identity of the surrounding farm areas. With many of the ads depicting the production of local commodities (pigs, eggs, chickens, dairy, wheat, corn, ducks, fish) on a Bunyanesque scale, WCCO distinguished itself from other large markets by emphasizing the vast natural resources of the Northwest, "a land of giant earnings." 46 Likewise, using a sleight of hand by which WCCO aligned Paul Bunyan with the Northwest and aligned themselves with both-suggesting "Northwest radio and WCCO Radio are, in truth, practically synonymous" - WCCO positioned itself as the only viable access point to the market's vast, resource-rich audiences. "If you would do big things in Paul Bunyanland, remember that it takes a giant to do a giant's job. You need the Northwest's 50,000-watt giant . . .WCCO RADIO." 47 By establishing the "Northwest Market" as unique, station representatives helped to define a particular audience commodity and legitimated the value of their own services as a means for sponsors to engage successfully with populations bounded by the geography of WCCO's reach.

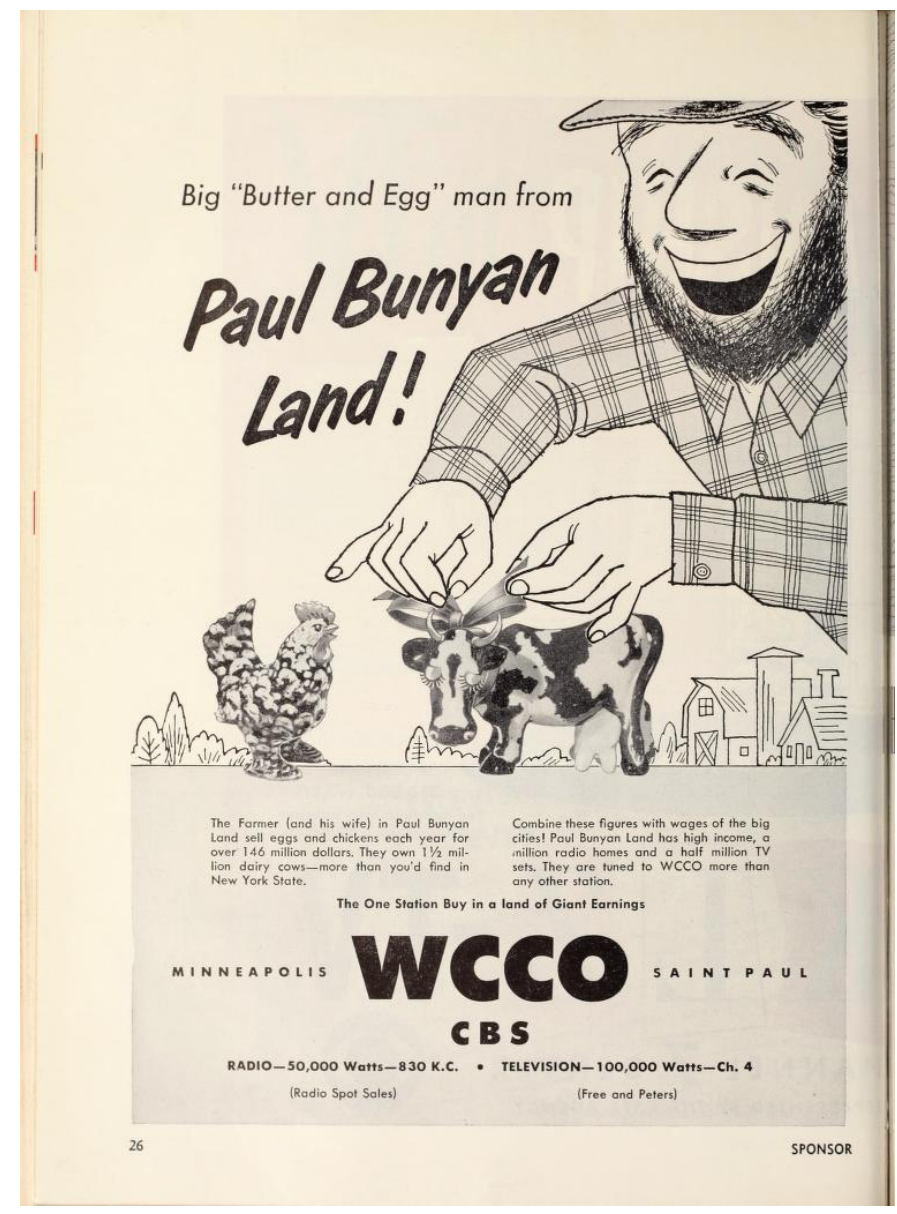

Figure 4. Sponsor, September 7, 1953: 26.

Myths, of course, are slippery-especially when invoked to provide meaning to otherwise undefined audiences-and Paul Bunyan, known for spanning the entire country with his 
outsized exploits, is perhaps even more flexible and open to appropriation than most. Indeed, several stations took up the folklore hero's name in their trade advertisements. KOIN-TV (Oregon and southern Washington, 1954), KIRO (Seattle and Tacoma, 1949), WBRE (Wyoming, 1952), and the Hildreth stations, WABI, WAGM, and WPOR (Bangor, Presque Isle, and Portland, Maine, 1959), all made use of Bunyan in one of their ads, touting the "gigantic" size of a new TV tower, the "mighty big" size of their operations, and the "giant proportions" of their coverage area. ${ }^{48}$ Bunyan even lent his name to a regional network in northern Wisconsin and Michigan; in addition to a single 1949 ad in Broadcasting mapping out the members and geography of its stations, the Paul Bunyan Network (radio and TV) ran twenty-eight ads in Broadcasting between 1959 and 1963.49 Although several ads alluded to Bunyan's size, the majority focused instead on owner Les Biederman, touting his trustworthy, enthusiastic, community-oriented personality and even his refurbished boat: ${ }^{50}$

\section{Stations DO Have Personality!}

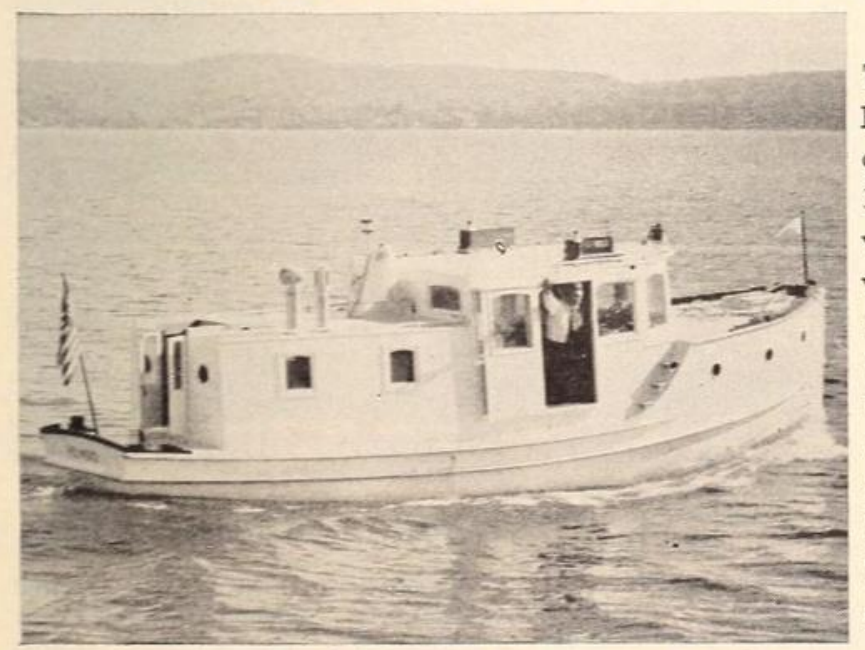

The personality here is the boat Ho-Maid, just put into the waters of Grand Traverse Bay, after $31 / 2$ years of "do-it-yourself" work by Pres. Les Biederman, who stripped a thirty-year, 35 foot commercial fishing boat to the hull and designed and built himself a diesel-powered, oceansafe boat. The project shows Les' imagination and staying power-imagination and staying power he has put into his seven stations-power that SELLS your product.

\section{The Paul Bunyan Stations}

\section{W PBN-TV •W TOM-TV $\bullet W T C M \bullet W M B N \bullet W A T T \bullet W A T C \bullet W A T Z$ Paul Bunyan Bldg. * Traverse City, Mich. * Venard, Torbet and McConnell, Inc.}

Figure 5. Broadcasting, October 28, 1963: 61.

Nevertheless, Bunyan enabled Biederman to metaphorically bind together several stations spanning expansive geographies. Bunyan's broad and continuing popularity as a self-branding device for a wide variety of stations across the northern United States indicates to some extent the arbitrary nature of stations' attempts to make their markets meaningful by drawing on useful cultural properties. It indicates the potential utility of "regional" folklore as one key avenue of distinction, even when Bunyan's storied roaming did not allow for exclusivity.

The final strategy taken up in WCCO advertising comprised station testimony regarding its close relationship with its listeners and their ensuing loyalty to WCCO stars (and sponsors). The 
"Good Neighbor to the Northwest" series mentioned above, for example, positioned WCCO as a valued companion to its listeners known for its neighborliness and emotional proximity notifying them of school closings, cheering on the local sports teams, filling the "grim" early hours of farm work with "chatter and cheerful noise," and providing important news. ${ }^{51}$ Other advertisements used mail volume and calls as metrics for the station's value to the local community. ${ }^{52}$ WCCO-TV campaigns later intensified this claim, positioning the television as "the other member of the family," literally transforming the set into a child. ${ }^{53}$

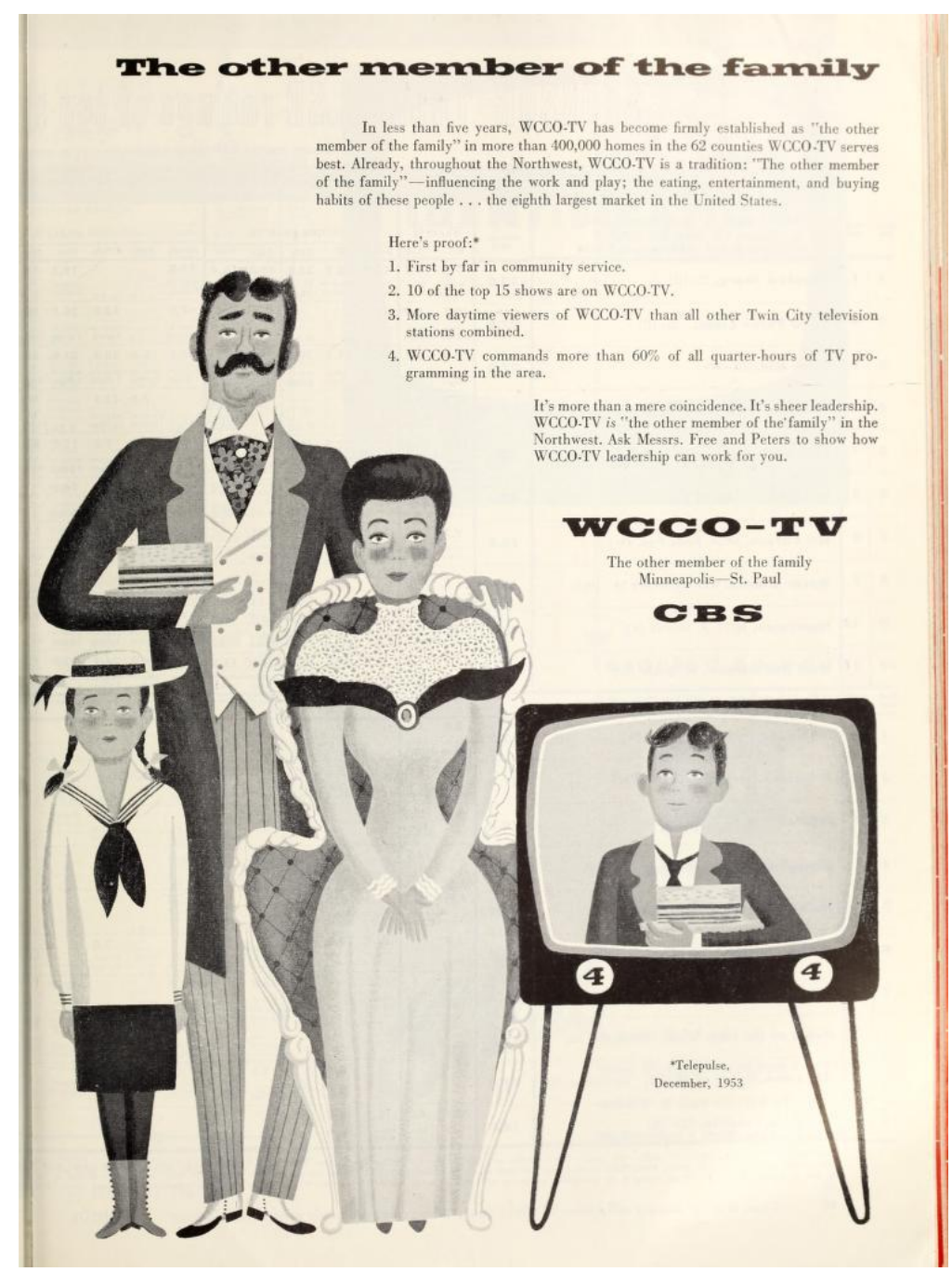

Figure 6. Sponsor, February 22, 1954: 43.

Since the primary users of spot advertising were national sponsors hoping to "localize" their messages, WCCO's claim to a special relationship with their listeners made for appealing advertising copy. ${ }^{54}$ In combining this strategy with those above, WCCO argued that it was not only its massive reach but its affective bond with a unique and valuable market that made the station an important local buy for sponsors. 


\section{Rereading WCCO (from Paul Bunyan's Level): The Wider Computational Context of Local Station Advertising}

While our WCCO case study provides necessary detail with regard to what station advertising campaigns actually looked like - as they were used by a major player in the trade press located through our initial SES calculations - it leaves us with more questions than can be answered with the above close-reading methods. How, for example, do WCCO's practices fit into the wider phenomenon of station trade press advertising? Can we take our case study as representative? Or does it represent an unusual outlier? For this-situating our case study within the complex sets of practices of local broadcasting as a whole-we must toggle back once again to the bird's-eye view afforded by Arclight.

As noted, the CSV file produced by Arclight provides a list of all 2,002 stations ranked by the amount of attention they received in the MHDL. Although not limited to trade journals (the results include fan magazines and other MHDL genres), the list provides a comparative hierarchy-additional computational context-that we can use to gauge stations against one another. To determine the representativeness of WCCO's engagement with journal advertising, we compared its practices to stations at the twenty-fifth, fiftieth, and seventy-fifth percentiles of our results. In each instance we looked at "peer clusters" of stations: small groups of six to ten stations with similar numerical results. Because the ranking is only a rough guide-considering the limitations of the entities, corpus, and digital mentioned above-using groups rather than single stations helps protect against taking singular or unusual stations as broadly representative of stations that appear at certain rank levels. In choosing WCCO, we became interested in outliers; in using SES to determine questions of shared practices and characteristics, we attempt to avoid them. We also compared WCCO to WSG and KFI, the two stations that immediately border the station at the very upper limits of our rankings. Ultimately, we compared WCCO to twenty-four other stations strategically chosen for their place within the full distribution of station mentions.

\begin{tabular}{lllllllll}
\hline \multicolumn{2}{l}{ Table 2. 50th Percentile Stations* } & & & & & \\
\hline & $\begin{array}{l}\text { Total } \\
\text { Hits, } \\
\text { MHDL }\end{array}$ & Broadcasting & Annuals & Sponsor & Variety & $\begin{array}{l}\text { U.S. } \\
\text { Radio }\end{array}$ & $\begin{array}{l}\text { Single- } \\
\text { Station } \\
\text { Ads }\end{array}$ & $\begin{array}{l}\text { Other } \\
\text { Ads }\end{array}$ \\
\hline WQUA & 314 & 194 & 100 & 17 & 0 & 0 & 22 & 0 \\
\hline WTTS & 314 & 115 & 87 & 20 & 47 & 9 & 0 & 0 \\
\hline WABZ & 314 & 124 & 71 & 7 & 0 & 2 & 0 & 0 \\
\hline WHBI & 316 & 126 & 99 & 19 & 43 & 0 & 1 & 0 \\
\hline WDVA & 317 & 137 & 142 & 30 & 0 & 8 & 0 & 0 \\
\hline WKWK & 317 & 135 & 156 & 11 & 4 & 1 & 0 & 1 \\
\hline WSTC & 318 & 136 & 134 & 30 & 1 & 9 & 3 & 0 \\
\hline WFIN & 318 & 130 & 111 & 9 & 7 & 9 & 0 & 0 \\
\hline WITA & 318 & 41 & 43 & 5 & 106 & 0 & 0 & 0 \\
\hline WDLP & 319 & 186 & 115 & 8 & 4 & 1 & 0 & 13 \\
\hline
\end{tabular}

*Described by total hits in trade journals carrying ads and total number of station advertisements found. 
Starting in the middle of our results and working out, it quickly becomes clear that most stations probably did not make significant use of station trade-journal advertisements. Indeed, an analysis of our bottom peer cluster (WAVU, WTBC, WTRR, WHBO, KXLQ, and WAGC, each of which boast 168 hits) reveals that only one, KXLQ, appeared in station advertisements. Furthermore, KXLQ (Bozeman, Montana) did not appear in single-station ads, but only in advertisements for a Pacific Northwest network, the "XL Stations" (so-called for the XL in their call signs, which ranged between seven and nine stations in the 1940s and '50s). Closer examination of page returns of peer cluster stations - which, despite their numerical similarity, often gathered "hits" in diverse ways-also provides further clues to factors that influence trending, from lawsuits and FCC trouble (WFIN, WDLP) to heavy promotion of public service programs (WDVA), and OCR (optical character recognition) problems (WITA). Peer-cluster comparison points to the utility of metadata in quickly identifying stations likely to bear certain characteristics. For example, the higher the ratio of station mentions in Broadcasting to annuals, the more likely stations are to participate in advertisements (it also helps us weed out the false positives of WITA, when we notice the dramatically high number of Variety mentions). The utility of metadata becomes even clearer in the chart below, which details metadata for seventyfifth percentile stations and WCCO's immediate cohort.

Table 3. 75th Percentile Stations and WCCO's Numerical Neighbors

\begin{tabular}{|c|c|c|c|c|c|c|c|c|c|}
\hline & $\begin{array}{l}\text { Total } \\
\text { MHDL }\end{array}$ & Hits, & Broadcasting & Annuals & Sponsor & Variety & $\begin{array}{l}\text { U.S. } \\
\text { Radio }\end{array}$ & $\begin{array}{l}\text { Single- } \\
\text { Station } \\
\text { Ads }\end{array}$ & $\begin{array}{l}\text { Other } \\
\text { Ads }\end{array}$ \\
\hline KLIF & 745 & & 483 & 104 & 112 & 3 & 28 & 14 & 56 \\
\hline WCMI & 750 & & 421 & 214 & 30 & 30 & 28 & 15 & 29 \\
\hline WKMH & 751 & & 477 & 159 & 88 & 0 & 14 & 104 & 114 \\
\hline WSBA & 752 & & 475 & 197 & 65 & 0 & 5 & 5 & 26 \\
\hline KROY & 754 & & 486 & 168 & 30 & 10 & 5 & 1 & 14 \\
\hline WCLO & 754 & & 346 & 207 & 6 & 28 & 1 & 11 & 18 \\
\hline KFI & 6,302 & & 2,670 & 452 & 142 & 619 & 13 & 70 & 119 \\
\hline WCCO & 6,307 & & 2,520 & 552 & 551 & 444 & 46 & 302 & 143 \\
\hline WGY & 6,317 & & 1,691 & 395 & 227 & 828 & 34 & 331 & 228 \\
\hline
\end{tabular}

Likewise, if we wanted to get a better sense of what contributes to WCCO's outlier status beyond its heavy use of ads, we could begin by looking at Sponsor, where our metadata indicates its coverage is double and even triple those in its peer cluster. Together, these two charts signal a dramatic rise in station mentions towards the top of the rankings, suggesting that trade coverage vastly overrepresents a minority of stations. While about 330 hits separate the fiftieth and seventy-fifth percentiles, those near the hundredth percentile received over 5,500 more hits than those at the seventy-fifth. More work is needed to see what additional factors contribute to this uneven trending. The latter chart, for example, underscores the extent to which station relationships with other industry institutions and agents support more hits. Networks, ${ }^{55}$ independent spot sales organizations, ${ }^{56}$ station representatives, ${ }^{57}$ equipment manufacturers, ${ }^{58}$ and even syndicators ${ }^{59}$ contribute significantly to station advertisements, 
outnumbering single-station ads for all but two of the above stations. Although this project began by focusing on stations alone, the SES process suggests the future productivity of expanding our entities to trace these dense industrial relationships.

Although the prominence of often dramatic and eye-catching advertisements in journals such as Broadcasting and Sponsor suggest that station advertising was a widespread industrial practice, according to our comparative analysis, we cannot take our case study to be representative of a majority activity (at least in terms of the extent to which WCCO purchased station advertisements). However, if we turn again to close reading to compare advertising strategies between stations, our case study appears less singular. Diverse stations' ads conform to WCCO's same strategies, from a focus on numbers and quantification ${ }^{60} \ldots$

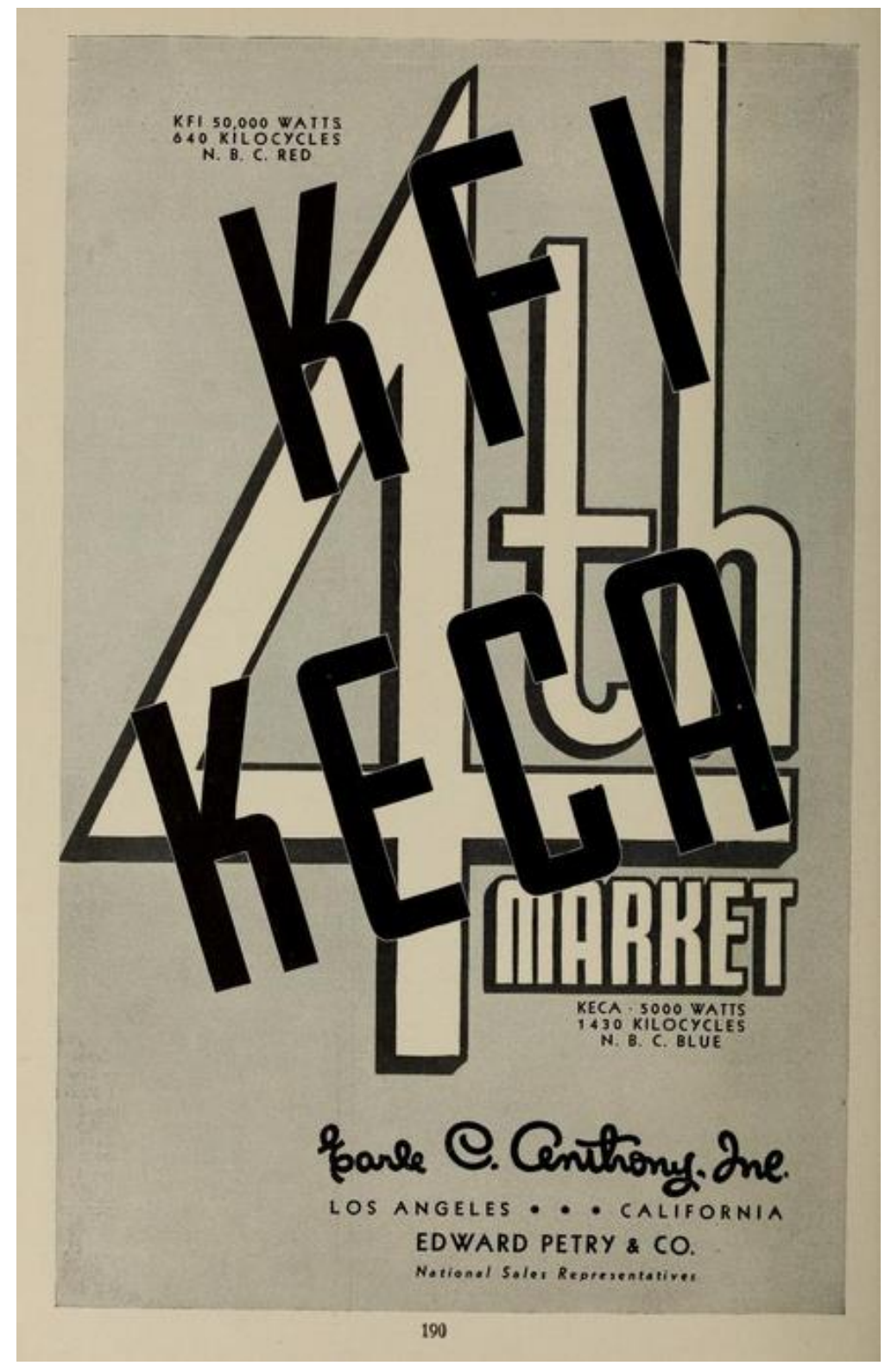

Figure 7. The 1938 Radio Annual: 190.

... to an emphasis on local culture ${ }^{61} \ldots$ 


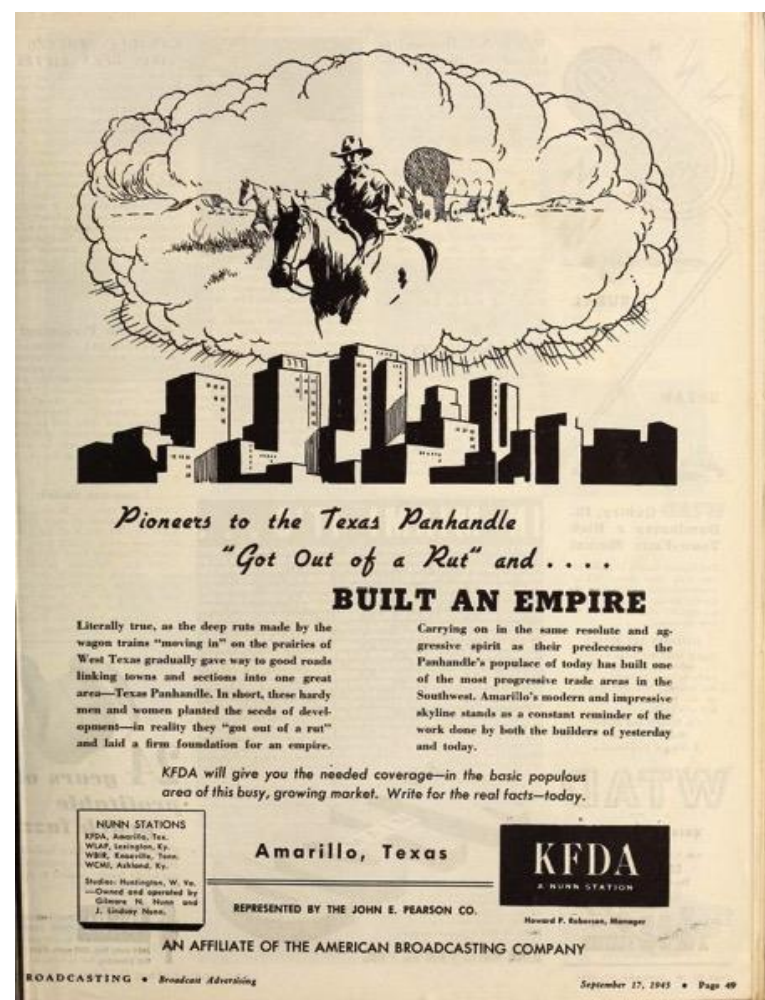

Figure 8. Broadcasting, September 17, 1945: 49.

... and the intimate bond between station and listener62:

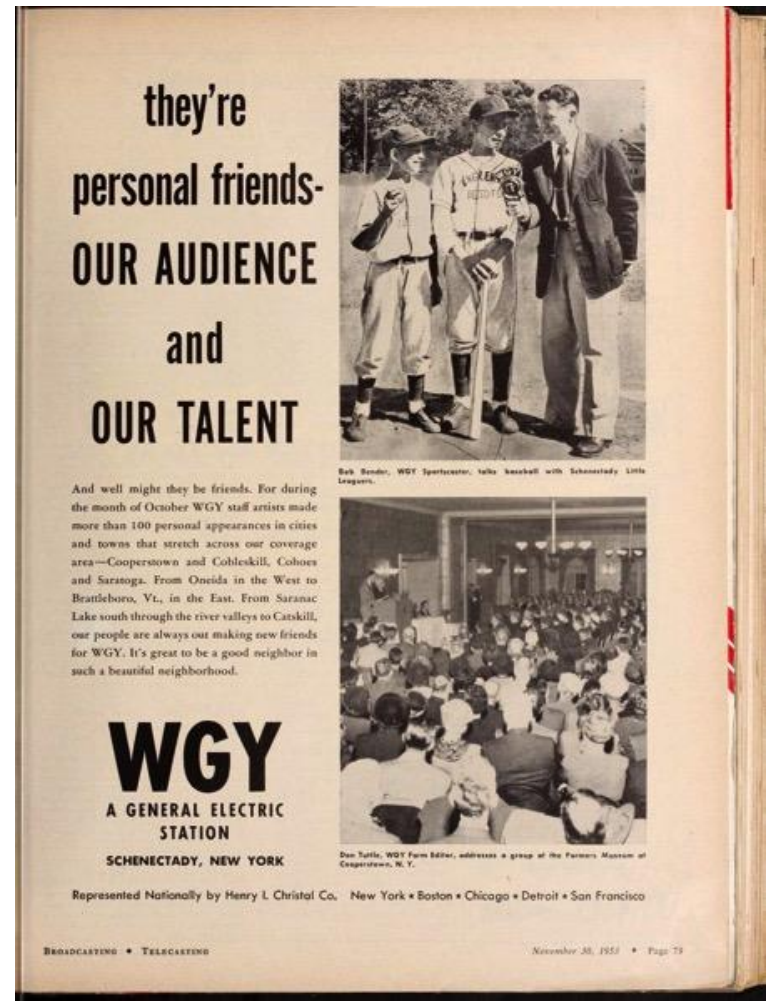

Figure 9. Broadcasting, November 30, 1953: 79. 
While looking beyond WCCO reinforced our initial understandings of station advertisement iconography - maps of all sorts, regions defined metonymically through local commodities - it also highlighted alternative strategies-for example, heavy emphasis on personalities and regionally specific programming, such as sports - that were present but not dominant in WCCO advertising. More research, particularly of high-ranked stations, could sketch out the full gamut of station advertising approaches. For now, however, we have an answer to our question regarding the representativeness of our case study. Qualitatively, but not quantitatively, WCCO stands as a useful entree into better understanding the strategies by which stations sought to make their markets appealing to advertisers.

\section{Conclusion}

Beyond its specific historical findings, our study of WCCO highlights one of the central, paradoxical conundrums of scholarship involving scaled digital datasets: how can scholars move from the "distant reading" of the set as a whole to the close reading of a case study, while also leveraging scale methodologically to place that case study within broader trends? We argue that scaled entity search provides one potential solution to this paradox because it permits selecting and situating case studies like WCCO in terms of their computational context. We found that digital tools can be most useful when they allow for and encourage frequent shuttling back and forth between multiple scales of data, as well as computer and human analysis, in an iterative approach to scholarship not unlike that which animates more traditional historical methods.

Nearly everything related to this project is openly accessible. We invite readers to try out the Arclight app on other radio call letters (or other entities entirely) and see where it leads them. We believe our study speaks to the vast possibilities for scholarship on local broadcasting, especially work that uses digital archives and tools. We hope that through approaches like scaled entity search, local historians and amateurs might harness the power of computational context to tell the stories of their own stations.

${ }^{1}$ Kit Hughes is Assistant Professor in the Department of Media, Journalism, and Film at Miami University in Ohio, where she's working on a book-length project exploring the rise of television within American business and industry. Her research on workplace media, television history, film aesthetics, and the politics of archives has appeared in Media, Culture E Society; Television \& New Media; American Archivist; and Film Criticism. Eric Hoyt is Assistant Professor of Media and Cultural Studies in the Department of Communication Arts at the University of Wisconsin-Madison. He is the author of Hollywood Vault: Film Libraries before Home Video (University of California Press, 2014) and codirector of the Media History Digital Library. He developed the MHDL's search and visualization platform, Lantern, which received the 2014 Anne Friedberg Innovative Scholarship Award from the Society for Cinema and Media Studies. Derek Long is a doctoral candidate in film at the University of Wisconsin-Madison, where his research focuses on distribution and production control in early Hollywood. His work has appeared in the Historical Journal of Film, Radio, and Television and The New Review of Film and Television Studies, and he is the project director for Early Cinema History Online. Kevin Ponto is Assistant Professor in the Design Studies Department at the school of Human Ecology and in the Living Environments Laboratory at the 
Wisconsin Institute for Discovery at the University of Wisconsin-Madison. His research explores the fields of virtual reality, wearable technology and visualization. $\mathrm{He}$ is the developer of ScripThreads, visualization software used to study the structures of character interactions in screenplays. Tony Tran is a doctoral candidate at the University of Wisconsin-Madison. His research focuses on transnational Vietnamese diasporic media practices and their relationship with urban environments.

2 Robert W. McChesney, Telecommunications, Mass Media, and Democracy: The Battle for the Control of U.S. Broadcasting, 1928-1935 (New York: Oxford University Press, 1993).

3 Erik Barnouw, The Golden Web: A History of Broadcasting in the United States, vol. 2, 1933 to 1953 (New York: Oxford University Press, 1968).

4 Michele Hilmes, Radio Voices: American Broadcasting, 1922-1952 (Minneapolis: University of Minnesota Press, 1997).

5 Susan J. Douglas, Listening In: Radio and the American Imagination (Minneapolis: University of Minnesota Press, 1999).

${ }^{6}$ Cynthia B. Meyers, A Word from Our Sponsor: Admen, Advertising, and the Golden Age of Radio (New York: Fordham University Press, 2014).

7 Alexander Russo, Points on the Dial: Golden Age Radio beyond the Networks (Durham, NC: Duke University Press, 2010), 3-4.

8 Ibid., 4.

${ }^{9}$ See “National Recording Preservation Plan," Library of Congress.

10 Wells H. Barnett Jr., "John Blair \& Company: WHB's New National Representatives," Swing, April 1947, 81.

${ }^{11}$ For more on the spot advertising marketplace, see Russo, Points on the Dial, 19-46, 115150, and Eric Hoyt, Hollywood Vault: Film Libraries before Home Video (Berkeley: University of California Press, 2014), 152-53.

12 The Arclight software's development, as well as the research discussed in this article, was sponsored by the United States' Institute for Museum and Library Services and Canada's Social Sciences and Humanities Research Council as part of a Digging into Data grant. Additional support came from the University of Wisconsin-Madison's Office of the Vice Chancellor for Research and Graduate Education and Concordia University's Media History Lab. We would like to thank the Concordia team, led by Charles Acland, for their collaboration throughout the research and development process. Additionally, we wish to thank the Media History Digital Library and its founder and director, David Pierce, for participating in Project Arclight.

13 See List of Wireless Telegraph Stations of the World (Washington, DC: Government Printing Office, 1909); 1912 version.

14 International Radiotelegraph Convention, Treaty Series 1913, no. 10, signed in London, July 5, 1912 (His Majesty's Stationary Office, printed by Harrison and Sons). Made available online by the International Telecommunications Union. Conference documents containing the assignment of call letters are available (see pp. 496-500).

${ }^{15}$ Radio Stations of the United States, Department of Commerce, Bureau of Navigation (Washington, DC: Government Printing Office, July 1913), 7.

${ }^{16}$ Radio Stations of the United States, 7. The United States Department of Commerce and the Bureau of Navigation made alternative arrangements for the regulation of amateur stations. 
17 These figures come from appendix C (Historical Statistics on Electronic Media) in Christopher H. Sterling and John Michael Kittross, Stay Tuned: A History of American Broadcasting (Mahwah, NJ: Lawrence Erlbaum Associates, 2002), 827.

18 An extensive resource for call-sign assignment information is Thomas H. White's website, United States Early Radio History. White's site stands as an excellent example of thriving digital humanities work taking place outside of the academy and the potential for collaboration (and locating new audiences) through digital projects.

19 There are also many instances of broadcasters attempting to retrofit their call signs to their stations. WSB, for example, claims its call letters stand for "Welcome South Brother"; however, WSB appears to have been awarded its letters in sequential order related to a larger chunk of WS- signs.

${ }^{20}$ For an example of the interpretive challenges offered by various disambiguation methods, see Seth van Hooland et al., "Exploring Entity Recognition and Disambiguation for Cultural Heritage Collections," Literary and Linguistic Computing 30, no. 2 (2015).

${ }^{21}$ We have uploaded the station data we collected to the Internet Archive and made it available for reuse. The data was collected from Jack Alicoate, ed., The 1948 Radio Annual (New York: Radio Daily, 1948), 291-730.

${ }^{22}$ N. W. Ayer E Son's Newspaper Annual Directory (Philadelphia): 1900-1950. We used editions located at the Wisconsin Historical Society. Several editions of the Ayer Annuals are also available online at HathiTrust. The N. W. Ayer \& Son data we collected are available for reuse.

${ }^{23}$ Ibid.

24 "Protect the Retailer: He's Here to Stay," Radio Dealer, April 1922, 27. In 1922, The Radio Dealer objected to advertisements for radio tubes and parts that appeared in magazines like Radio Digest, since these ads' invitation to readers to order directly from the manufacturer threatened retailers.

25 See, for instance, "Networks Seek Ways to Halt FCC Action," Broadcasting, May 12, 1941. See also Victor Pickard, America's Battle for Media Democracy: The Triumph of Corporate Libertarianism and the Future of Media Reform (New York: Cambridge University Press, 2015), 74, 88, 100.

${ }^{26}$ All of the above-mentioned journals were sponsored and digitized by the Library of Congress Packard Campus for Audiovisual Preservation and the Library of American Broadcasting at University of Maryland, College Park. Their efforts and generosity have enabled the MHDL's Broadcasting Collection to grow to over three hundred thousand pages. The MHDL's 1905-1941 run of Variety (95,996 pages) also contains a great deal of coverage of the broadcasting industry and radio's relationships with vaudeville and film.

27 SES's technical details are described fully in Eric Hoyt et al., "Scaled Entity Search: A Method for Media Historiography and Response to Critiques of Big Humanities Data Research," Proceedings of IEEE Big Humanities Data (2014).

${ }^{28}$ For a more comprehensive discussion of our interpretive method, see our website.

${ }^{29}$ If the latter case were our aim, other strategies - such as individually searching each discarded set of call letters with the station's frequency or location to locate relevant hits - could augment the automated SES method. 
30 "Old WLAG Reopens; New Letters WCCO," Radio Digest-Illustrated, October 18, $1924,3$.

31 "Nine Stations Given Maximum Power," Broadcasting, October 15, 1931, 8.

32 Lev Manovich, "How to Compare One Million Images?" in Understanding Digital Humanities, ed. David M. Berry (New York: Palgrave Macmillan, 2012), 249-98.

33 Although beyond the scope of this paper, a second set of questions might explore the advertising rates within each journal and magazine that might have influenced where and how advertisements appeared, or attempt to determine the economic significance of station advertisements to the papers' overall financial health.

34 Russo, Points on the Dial, 12.

35 For more on the role of station representatives in developing markets, see Russo, Points on the Dial, 17-46.

36 It is important to point out that the MHDL coverage of Variety ends in 1941 (as of 2015). WCCO station advertisements began to appear in Variety in 1938 and ran regularly through 1941. Though not accounted for in our SES results, it is highly likely that WCCO ads continued to appear in Variety beyond the early 1940s. When WCCO appears in fan magazines oriented toward the listening public, mentions tend to occur within the context of celebrity profiles, program descriptions, and radio listings. When ads appear, they tend to focus on the appeal of network stars, news, and other programming for potential listeners - rather than the appeal of potential listeners to advertisers and sponsors. See, for example, "The Stars That Shine in the Morning Are on the CBS Radio Network," TV Radio Mirror, May 1962, 4-5.

37 WCCO's dependence on these outside firms to make such claims is foregrounded in Sponsor, January 20,1964, 11, which notes that Nielsen would no longer measure local markets, but promises that "the audience is still there-listening and ready to be counted."

38 Hugh Malcolm Beville, Audience Ratings: Radio, Television, Cable (Hillsdale, NJ: Lawrence Erlbaum Associates, 1988).

${ }^{39}$ Rosser Reeves, Reality in Advertising (New York: Knopf, 1961), 33.

40 "Most-Crowded Newsroom in the Northwest," Broadcasting, August 16, 1943, 35.

${ }^{41}$ For example, see Broadcasting, July 28, 1952, 9, and "Minneapolis WCCO Saint Paul," Broadcasting, October 15, 1931, 27,. Both of these advertisements stack their figures vertically to simulate a sort of accounting that proves the economic viability of station spots. A similar strategy is evinced in Sponsor, July 20, 1964, 8-9.

42 Indeed, WCCO found itself in a position to be able to use such numbers to its advantage. See “Only on WCCO Radio," Broadcasting, November 27, 1961, 12-13.

43 This tagline appears both in CBS spot sales advertisements and in station-specific advertisements. See "This New CBS Power," Broadcasting, January 15, 1940, 4-7, and "Consistently the Largest Audience," Broadcasting, September 1, 1940, 53.

44 "Gateway to the Great Northwest," Broadcasting, September 1, 1932, 2.

45 Russo, Points on the Dial, 36.

46 “Big 'Butter and Egg' Man from Paul Bunyan Land!" Sponsor, September 7, 1953, 26.

47 "Great Friends," Sponsor, October 18, 1953, 93.

48 "Paul Bunyan Would Look Like a Midget ..." Sponsor, August 9, 1954, 103; "What He Uncovered-We Cover!," Broadcasting Telecasting, July 11, 1949, 2; “It's Coverage That 
Counts!," Broadcasting Telecasting, September 15, 1952, 16; “Maine in Top 50 Markets!," Broadcasting Telecasting, June 22, 1959, 97.

49 These likely continued, but 1963 marks the end of the journal's run in the MHDL. 50 “Paul Bunyan Networks Are Far Sighted!," Broadcasting October 28, 1959, 49.

51 "Kandiyohi Calling ... ." Broadcasting, July 5, 1943, 7; “Come into a Huddle with Hall," Broadcasting, August 28, 1944, 120-21; "Nobody Ever Threw a Clock at Lew Brock," Broadcasting, August 30, 1943, 37; "Adams Says We Just Bombed Berlin Again," Broadcasting, November 29, 1943, 41.

52 "Count Me In, Cedric!" Broadcasting Telecasting, September 19, 1955, 84-85.

53 "The Other Member of the Family," Sponsor, February 22, 1954.

54 Russo, Points on the Dial, 35.

${ }^{55}$ NBC (WGY), Nunn Stations (WCMI), NoeMoe Stations (KLIF).

${ }^{56}$ John Blair and Company (KLIF), Edward Petry \& Co (WKMH, KFI).

${ }^{57}$ Crowsley Station Representatives (WGY), Henry I. Christal Co. (WGY, KFI).

${ }^{58}$ RCA (WCCO), Continental (KFI).

59 Ziv (KFI).

${ }^{60}$ Jack Alicoate, ed., The 1938 Radio Annual, 190. See also, for example, WKMH's "33థ in Detroit," Broadcasting, November 21, 1949, 5.

61 See also WSG's "An EMPIRE within an Empire," Broadcasting, February 15, 1936, 47.

${ }^{62}$ See also WGY's "No School Today," Broadcasting, February 27, 1956, 11, which is remarkably similar to the WCCO "Kandiyohi Calling ..." ad cited above.

\section{Bibliography}

Alicoate, Jack, ed. The 1948 Radio Annual. New York: Radio Daily, 1948.

Barnouw, Erik. The Golden Web: A History of Broadcasting in the United States. Vol. 2, 1933 to 1953. New York: Oxford University Press, 1968.

Beville, Hugh Malcolm. Audience Ratings: Radio, Television, Cable. Hillsdale, NJ: Lawrence Erlbaum Associates, 1988.

Hilmes, Michele. Radio Voices: American Broadcasting, 1922-1952. Minneapolis: University of Minnesota Press, 1997.

Hoyt, Eric, Kit Hughes, Derek Long, Keven Ponto, and Anthony Tran. “Scaled Entity Search: A Method for Media Historiography and Response to Critiques of Big Humanities Data Research." Proceedings of IEEE Big Humanities Data (2014).

Manovich, Lev. "How to Compare One Million Images?" In Understanding Digital Humanities, edited by David M. Berry, 249-98. New York: Palgrave Macmillan, 2012.

McChesney, Robert W. Telecommunications, Mass Media, and Democracy: The Battle for the Control of U.S. Broadcasting, 1928-1935. New York: Oxford University Press, 1993.

Meyers, Cynthia B. A Word from Our Sponsor: Admen, Advertising, and the Golden Age of Radio. New York: Fordham University Press, 2014.

Reeves, Rosser. Reality in Advertising, New York: Knopf, 1961. 
Russo, Alexander. Points on the Dial: Golden Age Radio Beyond the Networks. Durham, NC: Duke University Press, 2010.

Sterling, Christopher H., and John Michael Kittross. Stay Tuned: A History of American Broadcasting. Mahwah, NJ: Lawrence Erlbaum Associates, 2002.

Susan J. Douglas, Listening In: Radio and the American Imagination. Minneapolis: University of Minnesota Press, 1999.

Van Hooland, Seth, Max De Wilde, Ruben Verborgh, Thomas Steiner, and Rick Van de Walle. "Exploring Entity Recognition and Disambiguation for Cultural Heritage Collections." Literary and Linguistic Computing 30, no. 2 (2015). 


\section{Appendix 1. List of Top 100 “Trending" Stations in Media History Digital Library Corpus, via Scaled Entity Search}

Notes: These have been postprocessed to remove unacceptably ambiguous results. Affiliation, ownership, and power information is accurate as of the publication of The 1948 Radio Annual. Page hits begin the year of each station's founding.

\begin{tabular}{|c|c|c|c|c|c|c|c|}
\hline $\begin{array}{l}\text { Call } \\
\text { Letters }\end{array}$ & City & Est. & Affiliation & Power & Freq. & Owner & $\begin{array}{l}\text { Page } \\
\text { Hits }\end{array}$ \\
\hline KDKA & Pittsburgh & 1920 & NBC & 50,000 & 1020 & $\begin{array}{l}\text { Westinghouse Radio } \\
\text { Stations, Inc. }\end{array}$ & 8,386 \\
\hline KYW & Philadelphia & 1921 & NBC & 50,000 & 1060 & $\begin{array}{l}\text { Westinghouse Radio } \\
\text { Stations, Inc. }\end{array}$ & 7,989 \\
\hline WBBM & Chicago & 1923 & CBS & 50,000 & 780 & $\begin{array}{l}\text { Columbia Broadcasting } \\
\text { System, Inc. }\end{array}$ & 7,752 \\
\hline $\begin{array}{l}\text { WBZ- } \\
\text { WBZA }\end{array}$ & $\begin{array}{l}\text { Boston \& } \\
\text { Springfield }\end{array}$ & 1921 & $\begin{array}{l}\text { NBC-New } \\
\text { England } \\
\text { Regional } \\
\text { Network }\end{array}$ & $\begin{array}{r}50,000 \\
(\text { WBZ) } \\
1,000 \\
(\text { WBZA) }\end{array}$ & 1030 & $\begin{array}{l}\text { Westinghouse Radio } \\
\text { Stations, Inc. }\end{array}$ & 7,644 \\
\hline WLS & Chicago & 1924 & $A B C$ & 50,000 & 890 & $\begin{array}{l}\text { Prairie Farmer Publishing } \\
\text { Co. }\end{array}$ & 7,339 \\
\hline $\mathrm{KHJ}$ & Los Angeles & 1922 & $\begin{array}{l}\text { MBS-Don } \\
\text { Lee }\end{array}$ & 5,000 & 930 & $\begin{array}{l}\text { Don Lee Broadcasting } \\
\text { System }\end{array}$ & 6,787 \\
\hline WGN & Chicago & 1924 & MBS & 50,000 & 720 & WGN, Inc. & 6,479 \\
\hline WSB & Atlanta & 1922 & NBC & 50,000 & 750 & $\begin{array}{l}\text { The Atlanta Journal Co., } \\
\text { Inc. }\end{array}$ & 6,393 \\
\hline WGY & Schenectady & 1922 & NBC & 50,000 & 810 & General Electric Co. & 6,317 \\
\hline WCCO & Minneapolis & 1924 & CBS & 50,000 & 830 & $\begin{array}{l}\text { Columbia Broadcasting } \\
\text { System, Inc. }\end{array}$ & 6,307 \\
\hline $\mathrm{KFI}$ & Los Angeles & 1922 & NBC & 50,000 & 640 & Earle C. Anthony & 6,302 \\
\hline KGO & San Francisco & 1924 & $A B C$ & 50,000 & 810 & American Broadcasting Co. & 6,253 \\
\hline WFAA & Dallas & 1922 & $\begin{array}{l}\text { NBC-ABC- } \\
\text { Texas } \\
\text { Quality } \\
\text { Network }\end{array}$ & $\begin{array}{r}50,000 / \\
5,000 \\
\end{array}$ & $\begin{array}{r}820 / \\
570 \\
\end{array}$ & A. H. Belo Corp. & 6,177 \\
\hline WMAQ & Chicago & 1922 & NBS & 50,000 & 670 & National Broadcasting Co. & 5,903 \\
\hline WNEW & New York & 1934 & NULL & 10,000 & 1130 & $\begin{array}{l}\text { Greater N. Y. Broadcasting } \\
\text { Corp. }\end{array}$ & 5,863 \\
\hline WHAS & Louisville & 1922 & CBS & 50,000 & 840 & $\begin{array}{l}\text { The Courier-Journal \& } \\
\text { Louisville Times Co. }\end{array}$ & 5,614 \\
\hline WJR & Detroit & 1922 & CBS & 50,000 & 760 & The Goodwill Station, Inc. & 5549 \\
\hline WRC & $\begin{array}{l}\text { Washington, } \\
\text { DC }\end{array}$ & 1923 & NBC & 5,000 & 980 & National Broadcasting Co. & 5,441 \\
\hline WSM & Nashville & 1925 & NBC & 50,000 & 650 & WSM, Inc. & 5,280 \\
\hline WGR & Buffalo & 1922 & CBS & 5,000 & 550 & WGR Broadcasting Corp. & 5,154 \\
\hline WBAP & Fort Worth & 1922 & $\begin{array}{l}\text { NBC-ABC- } \\
\text { LSC-Texas } \\
\text { Quality } \\
\text { Network }\end{array}$ & $\begin{array}{r}50,000 / \\
5,000 \\
\end{array}$ & $\begin{array}{c}820 / \\
570\end{array}$ & Carter Publications, Inc. & 5,055 \\
\hline
\end{tabular}




\begin{tabular}{|c|c|c|c|c|c|c|c|}
\hline WTIC & Hartford & 1925 & $\begin{array}{l}\text { NBC-New } \\
\text { England } \\
\text { Regional } \\
\text { Network }\end{array}$ & 50,000 & 1080 & $\begin{array}{l}\text { Travelers Broadcasting } \\
\text { Service Corp. }\end{array}$ & 4,999 \\
\hline WBAL & Baltimore & 1925 & NBC & 50,000 & 1090 & Hearst Radio, Inc. & 4,984 \\
\hline KMOX & St. Louis & 1925 & CBS & 50,000 & 1120 & $\begin{array}{l}\text { Columbia Broadcasting } \\
\text { System, Inc. }\end{array}$ & 4,967 \\
\hline WHB & Kansas City & 1922 & $\begin{array}{l}\text { MBS-Kansas } \\
\text { State } \\
\text { Network }\end{array}$ & $\begin{array}{r}10,000 \mathrm{~d} \\
5,000 \mathrm{n} \\
\end{array}$ & 710 & WHB Broadcasting Co. & 4,877 \\
\hline WOC & Davenport & 1922 & NBC & 5,000 & 1420 & TriCity Broadcasting Co. & 4,841 \\
\hline KMBC & Kansas City & 1921 & CBS & 5,000 & 980 & Midland Broadcasting Co. & 4,543 \\
\hline WEEI & Boston & 1924 & CBS & 5,000 & 590 & $\begin{array}{l}\text { Columbia Broadcasting } \\
\text { System, Inc. }\end{array}$ & 4,540 \\
\hline KGW & Portland, OR & 1922 & NBC & 5,000 & 620 & The Oregonian Publ. Co. & 4,535 \\
\hline KFWB & Hollywood & 1925 & NULL & 5,000 & 980 & Warner Bros. Broadcasting & 4,534 \\
\hline WSAI & Cincinnati & 1923 & $A B C$ & 5,000 & 1360 & Marshall Field & 4,523 \\
\hline WHK & Cleveland & 1921 & MBS & 5,000 & 1420 & United Broadcasting Co. & 4,424 \\
\hline WMC & Memphis & 1922 & NBC & 5,000 & 790 & Memphis Publishing Co. & 4,357 \\
\hline KNX & Los Angeles & 1937 & $\begin{array}{l}\text { CBS- } \\
\text { Columbia } \\
\text { Pacific } \\
\text { Network }\end{array}$ & 50,000 & 1070 & $\begin{array}{l}\text { Columbia Broadcasting } \\
\text { System }\end{array}$ & 4,275 \\
\hline WHAM & Rochester & 1922 & NBC & 50,000 & 1180 & Stromberg-Carlson Co. & 4,274 \\
\hline WMT & Cedar Rapids & 1922 & CBS & 5,000 & 600 & $\begin{array}{l}\text { American Broadcasting } \\
\text { Stations, Inc. }\end{array}$ & 4,271 \\
\hline WCBS & New York & 1924 & CBS & 50,000 & 880 & $\begin{array}{l}\text { Columbia Broadcasting } \\
\text { System, Inc. }\end{array}$ & 4,269 \\
\hline WKY & Oklahoma City & 1928 & NBC & 5,000 & 930 & Oklahoma Publ. Co. & 4,255 \\
\hline WTAM & Cleveland & 1923 & NBC & 50,000 & 1100 & $\begin{array}{l}\text { National Broadcasting Co., } \\
\text { Inc. }\end{array}$ & 4,237 \\
\hline WDAF & Kansas City & 1922 & NBC & 5,000 & 610 & The Kansas City Star Co. & 4,235 \\
\hline WKRC & Cincinnati & 1923 & CBS & $\begin{array}{r}5,000 ; \\
1,000 n \\
\end{array}$ & 550 & $\begin{array}{l}\text { The Cincinnati Times-Star } \\
\text { Co. }\end{array}$ & 4,221 \\
\hline WCAE & Pittsburgh & 1922 & $A B C$ & 5,000 & 1250 & WCAE, Inc. & 4,217 \\
\hline WBT & Charlotte & 1921 & CBS & 50,000 & 1110 & $\begin{array}{l}\text { Jefferson Standard } \\
\text { Broadcasting Co. }\end{array}$ & 4,141 \\
\hline WNAC & Boston & 1922 & $\begin{array}{l}\text { MBS-The } \\
\text { Yankee } \\
\text { Network }\end{array}$ & 5,000 & 1260 & General Tire \& Rubber Co. & 4,079 \\
\hline KLZ & Denver & 1922 & CBS & 5,000 & 560 & KLZ Broadcasting Co. & 4,061 \\
\hline WJZ & New York & 1921 & $A B C$ & 50,000 & 770 & American Broadcasting Co. & 4,041 \\
\hline WOAl & San Antonio & 1922 & $\begin{array}{l}\text { NBC-Texas } \\
\text { Quality } \\
\text { Network }\end{array}$ & 50,000 & 1200 & Southland Industries, Inc. & 4,027 \\
\hline
\end{tabular}




\begin{tabular}{|c|c|c|c|c|c|c|c|}
\hline KSTP & $\begin{array}{l}\text { St. Paul- } \\
\text { Minneapolis }\end{array}$ & 1928 & $\begin{array}{l}\text { NBC- } \\
\text { Northwest } \\
\text { Network }\end{array}$ & 50,000 & 1500 & KSTP, Inc. & 4,019 \\
\hline WXYZ & Detroit & 1930 & $A B C$ & 5,000 & 1270 & $\begin{array}{l}\text { American Broadcasting } \\
\text { Corp. }\end{array}$ & 3,831 \\
\hline WGAR & Cleveland & 1930 & CBS & 50,000 & 1220 & $\begin{array}{l}\text { The WGAR Broadcasting } \\
\text { Co. }\end{array}$ & 3,763 \\
\hline $\mathrm{KFAB}$ & Omaha & 1924 & CBS & 50,000 & 1110 & FFAB Broadcasting Co. & 3,709 \\
\hline KSL & Salt Lake City & 1924 & CBS & 50,000 & 1160 & Radio Service Corp. of Utah & 3,510 \\
\hline WOL & $\begin{array}{l}\text { Washington, } \\
\text { DC }\end{array}$ & 1924 & MBS & 5,000 & 1260 & $\begin{array}{l}\text { Cowles Broadcasting } \\
\text { System }\end{array}$ & 3,477 \\
\hline KFRC & San Francisco & 1924 & $\begin{array}{l}\text { MBS-Don } \\
\text { Lee }\end{array}$ & 5,000 & 610 & $\begin{array}{l}\text { Don Lee Broadcasting } \\
\text { System }\end{array}$ & 3,469 \\
\hline WJAR & Providence & 1922 & $\begin{array}{l}\text { NBC-New } \\
\text { England } \\
\text { Regional }\end{array}$ & 5,000 & 920 & The Outlet Co. & 3,434 \\
\hline WCKY & Cincinnati & 1929 & NULL & 50,000 & 1530 & L. B. Wilson, Inc. & 3,419 \\
\hline WSYR & Syracuse & 1922 & NBC & 5,000 & 570 & Central N. Y. Broadcasting & 3,335 \\
\hline WJJD & Chicago & 1932 & NULL & 50,000 & 1160 & Field Enterprises, Inc. & 3,319 \\
\hline WOWO & Fort Wayne & 1925 & $A B C$ & 10,000 & 1190 & $\begin{array}{l}\text { Westinghouse Radio } \\
\text { Stations, Inc. }\end{array}$ & 3,287 \\
\hline WFBM & Indianapolis & 1924 & CBS & 5,000 & 1260 & WFBM, Inc. & 3,284 \\
\hline $\mathrm{KOIN}$ & Portland & 1925 & CBS & 5,000 & 970 & KOIN, Inc. & 3,264 \\
\hline KECA & Los Angeles & 1929 & $A B C$ & 5,000 & 790 & $\begin{array}{l}\text { American Broadcasting } \\
\text { Co., Inc. }\end{array}$ & 3,263 \\
\hline WSPD & Toledo & 1921 & NBC & 5,000 & 1370 & The Fort Industry Co. & 3,239 \\
\hline WENR & Chicago & 1923 & $A B C$ & 50,000 & 890 & American Broadcasting Co. & 3,205 \\
\hline WHP & Harrisburg & 1924 & CBS & $\begin{array}{r}5,000 \mathrm{~d} ; \\
1,000 \mathrm{n}\end{array}$ & 1460 & WHP, Inc. & 3,193 \\
\hline WTAG & Worcester & 1924 & CBS & 5,000 & 580 & WTAG, Inc. & 3,167 \\
\hline WDSU & New Orleans & 1923 & $\begin{array}{l}\text { ABC- } \\
\text { Louisiana } \\
\text { State-United } \\
\text { Nations }\end{array}$ & 5,000 & 1280 & Stephens Broadcasting Co. & 3,154 \\
\hline KOIL & Omaha & 1925 & $\begin{array}{l}\text { ABC- } \\
\text { Nebraska } \\
\text { Network }\end{array}$ & 5,000 & 1290 & $\begin{array}{l}\text { Central State Broadcasting } \\
\text { Co. }\end{array}$ & 3,131 \\
\hline KVOO & Tulsa & 1925 & NBC & 50,000 & 1170 & Southwestern Sales Corp. & 3,121 \\
\hline $\mathrm{KOMO}$ & Seattle & 1926 & NBC & 5,000 & 1000 & Fisher's Blend Station, Inc. & 3,097 \\
\hline WTOP & $\begin{array}{l}\text { Washington, } \\
\text { DC }\end{array}$ & 1928 & CBS & 50,000 & 1500 & $\begin{array}{l}\text { Columbia Broadcasting } \\
\text { System }\end{array}$ & 3,095 \\
\hline $\mathrm{KOB}$ & Albuquerque & 1920 & NBC-MBS & $\begin{array}{r}50,000 \mathrm{~d} ; \\
25,000 \mathrm{n}\end{array}$ & 770 & $\begin{array}{l}\text { Albuquerque Broadcasting } \\
\text { Co. }\end{array}$ & 3,091 \\
\hline WTAR & Norfolk & 1923 & NBC & 5,000 & 790 & Norfolk Newspaper, Inc. & 3,053 \\
\hline WJBK & Detroit & 1926 & NULL & 250 & 1490 & Detroit Broadcasting Co. & 3,049 \\
\hline WCAU & Philadelphia & 1922 & CBS & 50,000 & 1210 & Philadelphia Record Co. & 3,036 \\
\hline
\end{tabular}




\begin{tabular}{|c|c|c|c|c|c|c|c|}
\hline WBEN & Buffalo & 1930 & NBC & 5,000 & 930 & Buffalo Evening News & 3,009 \\
\hline KWK & St. Louis & 1927 & MBS & $\begin{array}{r}5,000 \\
1,000 \mathrm{n}\end{array}$ & 1380 & Thomas Patrick, Inc. & 2,972 \\
\hline WRVA & Richmond & 1925 & CBS & 50,000 & 1140 & Larus \& Brother Co. & 2,939 \\
\hline WFIL & Philadelphia & 1922 & $A B C$ & 5,000 & 560 & $\begin{array}{l}\text { The Philadelphia Inquirer } \\
\text { Div. of Triangle Publications, } \\
\text { Inc. }\end{array}$ & 2,938 \\
\hline KMPC & Bakersfield & 1924 & $A B C$ & 1,000 & 1560 & Pioneer Mercantile Co. & 2,920 \\
\hline WMBD & Peoria & 1927 & CBS & 5,000 & 1470 & Peoria Broadcasting Co. & 2,904 \\
\hline WBNS & Columbus & 1924 & CBS & $\begin{array}{r}5,000 \mathrm{~d} \\
1,000 \mathrm{n}\end{array}$ & 1460 & Radionio, Inc. & 2,897 \\
\hline WTCN & Minneapolis & 1934 & $\begin{array}{l}\text { ABC- } \\
\text { Dairyland } \\
\text { Network }\end{array}$ & $\begin{array}{r}5,000 \\
1,000 n \\
\end{array}$ & 1280 & $\begin{array}{l}\text { Minnesota Broadcasting } \\
\text { Corp. }\end{array}$ & 2,892 \\
\hline KEX & Portland, OR & 1926 & $A B C$ & $\begin{array}{r}5,000 ; \mathrm{cp} \\
50,000 \\
\end{array}$ & 1190 & $\begin{array}{l}\text { Westinghouse Radio } \\
\text { Stations, Inc. }\end{array}$ & 2,885 \\
\hline WWL & New Orleans & 1922 & CBS & 50,000 & 870 & Loyola University & 2,830 \\
\hline KDYL & Salt Lake City & 1922 & $\begin{array}{l}\text { NBC-Utah- } \\
\text { Idaho } \\
\text { Network }\end{array}$ & 5,000 & 1320 & $\begin{array}{l}\text { Intermountain Broadcasting } \\
\text { Corp. }\end{array}$ & 2,709 \\
\hline KSFO & San Francisco & 1925 & NULL & $\begin{array}{r}5,000 \\
1,000 n\end{array}$ & 560 & $\begin{array}{l}\text { The Associated } \\
\text { Broadcasters, Inc. }\end{array}$ & 2,673 \\
\hline WNAX & Yankton & 1927 & $A B C$ & 5,000 & 570 & Cowles Broadcasting Co. & 2,645 \\
\hline WWDC & $\begin{array}{l}\text { Washington, } \\
\text { DC }\end{array}$ & 1941 & NULL & 250 & 1450 & Capital Broadcasting Co. & 2,643 \\
\hline WGAL & Lancaster & 1922 & NBC-MBS & 250 & 1490 & WGAL, Inc. & 2,643 \\
\hline WWJ & Detroit & 1920 & NBC & 5,000 & 950 & Evening News Assoc. & 2,537 \\
\hline WMAL & $\begin{array}{l}\text { Washington, } \\
\text { DC }\end{array}$ & 1925 & $A B C$ & 5,000 & 630 & The Evening Star & 2,149 \\
\hline KTHS & Hot Springs & 1924 & $A B C$ & $\begin{array}{r}10,000 \mathrm{~d} \\
5,000 \mathrm{n} \\
\end{array}$ & 1090 & Times Publishing Co., Ltd. & 2,106 \\
\hline WTMJ & Milwaukee & 1927 & NBC & 5,000 & 620 & The Journal Co. & 2,027 \\
\hline WIP & Philadelphia & 1922 & MBS & 5,000 & 610 & Penn. Broadcasting Co. & 1,945 \\
\hline KPRC & Houston & 1925 & $\begin{array}{l}\text { NBC-Texas } \\
\text { Quality } \\
\text { Network }\end{array}$ & 5000 & 950 & The Houston Post Co. & 1,943 \\
\hline $\mathrm{KOA}$ & Denver & 1924 & NBC & 50,000 & 850 & National Broadcasting Co. & 1,748 \\
\hline KSD & St. Louis & 1922 & NBC & 5,000 & 550 & Pulitzer Publishing Co. & 1,501 \\
\hline WIBW & Topeka & 1924 & CBS & 5,000 & 580 & Capper Publications, Inc. & 1,355 \\
\hline CKLW & Detroit-Windsor & 1932 & MBS-CBC & 5,000 & 800 & Essex Broadcasting, Inc. & 1,317 \\
\hline
\end{tabular}

\section{(cc) EY-NC-ND}

Copyright (c) 2015 (Kit Hughes, Eric Hoyt, Derek Long, Kevin Ponto, and Tony Tran). Media Industries is an open-access, peer-reviewed, online academic journal. As such, we aim to participate in the open exchange of information. This work is licensed under a Creative Commons Attribution Noncommercial No Derivatives (by-nc-nd) License. Under this license, this work is available for sharing and noncommercial distribution provided the appropriate attribution is given. 